\title{
Arbeidsmarktscanner Rijksuniversiteit Limburg : basismeting cohort '92
}

Citation for published version (APA):

Ramaekers, G. W. M. (1994). Arbeidsmarktscanner Rijksuniversiteit Limburg : basismeting cohort '92. Researchcentrum voor Onderwijs en Arbeidsmarkt, Faculteit der Economische Wetenschappen. ROA Reports No. 7 https://doi.org/10.26481/umarep.1994007

Document status and date:

Published: 01/01/1994

DOI:

10.26481/umarep.1994007

Document Version:

Publisher's PDF, also known as Version of record

\section{Please check the document version of this publication:}

- A submitted manuscript is the version of the article upon submission and before peer-review. There can be important differences between the submitted version and the official published version of record.

People interested in the research are advised to contact the author for the final version of the publication, or visit the DOI to the publisher's website.

- The final author version and the galley proof are versions of the publication after peer review.

- The final published version features the final layout of the paper including the volume, issue and page numbers.

Link to publication

\footnotetext{
General rights rights.

- You may freely distribute the URL identifying the publication in the public portal. please follow below link for the End User Agreement:

www.umlib.nl/taverne-license

Take down policy

If you believe that this document breaches copyright please contact us at:

repository@maastrichtuniversity.nl

providing details and we will investigate your claim.
}

Copyright and moral rights for the publications made accessible in the public portal are retained by the authors and/or other copyright owners and it is a condition of accessing publications that users recognise and abide by the legal requirements associated with these

- Users may download and print one copy of any publication from the public portal for the purpose of private study or research.

- You may not further distribute the material or use it for any profit-making activity or commercial gain

If the publication is distributed under the terms of Article $25 \mathrm{fa}$ of the Dutch Copyright Act, indicated by the "Taverne" license above, 
Arbeidsmarktscanner Rijksuniversiteit Limburg:

Basismeting cohort '92

ROA-R-1994/7

G.W.M. Ramaekers

Researchcentrum voor Onderwijs en Arbeidsmarkt

Faculteit der Economische Wetenschappen

Rijksuniversiteit Limburg

Maastricht, oktober 1994 
Bijlage 1 Tabellen afstudeerrichtingen FdGW en FdEW

Bijlage 2 Definitie van variabelen in de schattingen

Bijlage 3 ROA-publicaties in het kader van de arbeidsmarktscanner 


\section{Verantwoording}

Het Researchcentrum voor Onderwijs en Arbeidsmarkt (ROA) verricht sinds 1990 periodiek onderzoek naar de arbeidsmarktpositie en loopbanen van afgestudeerden van de Rijksuniversiteit Limburg (RL). Dit gebeurt met behulp van de zogeheten 'Arbeidsmarktscanner RL'. De systematiek van deze scanner, zoals deze thans aan de RL wordt toegepast, bestaat hieruit dat oudstudenten voor de eerste keer circa één jaar na het afstuderen worden bevraagd met behulp van een basisvragenlijst (de basismeting). Vijf jaar later worden zij opnieuw geënquêteerd met een loopbaanvragenlijst. Hiermee kunnen zij ontwikkelingen, die zich sinds de eerste bevraging in de loopbaan hebben voorgedaan, retrospectief doorgeven (de loopbaanmeting).

In het nu voorliggende rapport worden de resultaten gepresenteerd van de basismeting onder degenen die in 1992 aan de RL zijn afgestudeerd. Deze populatie van nieuw-afgestudeerden is in het najaar van 1993 met behulp van de basisvragenlijst geënquêteerd.

De arbeidsmarktscanner wordt aan de $\mathrm{RL}$ toegepast in opdracht van het College van Bestuur. De toepassing vindt plaats in samenwerking met de Dienst Studentenzaken van de RL. De Dienst Studentenzaken zorgt voor het bijhouden van het adressenbestand van afgestudeerden, het verzenden van de vragenlijsten en de non-respons activiteiten. Het ROA is verantwoordelijk voor de methodologische en inhoudelijke aspecten van de arbeidsmarktscanner, stelt de jaarlijkse rapportages samen en beheert het bestand met onderzoeksgegevens. Het onderzoek wordt binnen het ROA uitgevoerd door drs. G.W.M. Ramaekers (projectleider) met medewerking van J.M.J.A. Pisters. Het project wordt intern begeleid door dr. R.K.W. van der Velden en prof. dr. J.A.M. Heijke.

Er dient op te worden gewezen dat de in dit rapport gepresenteerde onderzoekresultaten uitsluitend betrekking hebben op afgestudeerden van de RL. Pas door een landelijke toepassing van de arbeidsmarktscanner kan de vraag worden beantwoord in hoeverre de in dit rapport gepresenteerde arbeidsmarktpositie en functiekenmerken van afgestudeerden van de RL instellingsspecifiek zijn, dan wel worden gedomineerd door de landelijke situatie met betrekking tot universitaire afgestudeerden. 



\section{Inleiding}

Oudstudenten van de RL worden ongeveer één jaar na het afstuderen schriftelijk geënquêteerd met behulp van de zogeheten basisvragenlijst. Deze basisvragenlijst bevat vragen over de persoon, de afgesloten opleiding, de vooropleiding, de eventuele werk- en bestuurservaring vóór het afstuderen, de belangrijkste activiteiten na het afstuderen tot het moment van enquêteren, de huidige arbeidsmarktpositie, eventueel gevolgd onderwijs na het afstuderen en, bij betaald-werkenden, enkele kenmerken van de huidige functie en van de organisatie waarin men werkzaam is. De definitie en classificatie van de variabelen sluiten waar mogelijk aan bij de gangbare omschrijvingen en indelingen die worden gehanteerd door het Centraal Bureau voor de Statistiek (CBS).

De onderzoekspopulatie van de Arbeidsmarktscanner RL bestaat op dit moment uit degenen die een doctoraal-getuigschrift hebben gehaald aan de Faculteit der Gezondheidswetenschappen (FdGW), de Faculteit der Rechtsgeleerdheid (FdR) of de Faculteit der Economische Wetenschappen (FdEW), alsmede degenen die aan de Faculteit der Geneeskunde (FdG) voor het basisartsexamen zijn geslaagd. In het najaar van 1993 zijn degenen die in 1992 aan de bovengenoemde faculteiten van de RL zijn afgestudeerd met behulp van de basisvragenlijst schriftelijk geënquêteerd. Het onderhavige rapport doet verslag van de onderzoeksresultaten van deze basismeting. Het is de vijfde keer dat een dergelijke basismeting bij een afstudeercohort van de RL plaatsvindt. In eerder gehouden enquêtes zijn degenen die in de tweede helft van 1988 zijn afgestudeerd (hierna aangeduid als cohort '88), alsmede cohort '89, cohort '90 en cohort '91 met de basisvragenlijst benaderd. De resultaten van de eerder gehouden basismetingen onder achtereenvolgens de afstudeercohorten ' 88 en ' $89^{1}$, afstudeercohort ' $90^{2}$ en afstudeerjaargang ' $91^{3}$ zijn in vroegere rapportages aan bod gekomen.

Bij afstudeerjaargang '92 gaat het om in totaal 784 afgestudeerden, waarvan er 603 de vragenlijst ingevuld hebben geretourneerd. De 'overall' respons bedraagt derhalve 77\%. Tabel 1.1 geeft, onderverdeeld naar faculteit, voor afstudeercohort '92 een overzicht van de absolute en relatieve aantallen afgestudeerden en respondenten en de daaruit resulterende responspercentages. Naar voren komt dat de respons onder gezondheidswetenschappers het hoogst en onder economen het laagst is. Dit leidt ertoe dat gezondheidswetenschappers met 4\%-punt zijn oververtegenwoordigd in de steekproef, terwijl economen met 3\%-punt zijn ondervertegenwoordigd. Basisartsen en juristen zijn naar rato van hun aandeel in de totale populatie vertegenwoordigd in de steekproef.

In dit rapport worden de resultaten van de basismeting onder de afgestudeerden van cohort '92 gepresenteerd. De tabellen zijn steeds uitgesplitst naar faculteit. Verschillen tussen faculteiten worden echter alleen besproken wanneer deze statistisch significant zijn. In bijlage 1 zijn voor achtereenvolgens de FdGW en de FdEW enkele additionele tabellen opgenomen met kerngegevens over de vijf tot nu toe geënquêteerde cohorten, waarbij uitsplitsingen naar afstudeervariant zijn gemaakt.

\footnotetext{
1. Ramaekers en Heijke (1991).

2. Ramaekers en Heijke (1993-1).

3. Ramaekers en Heijke (1993-2).
} 


\begin{tabular}{|c|c|c|c|}
\hline & $\begin{array}{l}\mathrm{N} \text { afgestudeerden } \\
\text { abs. } \%\end{array}$ & $\begin{array}{r}\mathrm{n} \text { respondenten } \\
\text { abs. } \%\end{array}$ & $\begin{array}{l}\text { respons } \\
\%\end{array}$ \\
\hline $\begin{array}{l}\text { FdG } \\
\text { FdGW } \\
\text { FdR } \\
\text { FdEW }\end{array}$ & $\begin{array}{r}84 \\
377 \\
165 \\
158\end{array}$ & $\begin{array}{r}62 \\
313 \\
123 \\
105\end{array}$ & $\begin{array}{l}74 \\
83 \\
75 \\
66\end{array}$ \\
\hline $\mathrm{RL}$ & 784 & 603 & 77 \\
\hline
\end{tabular}

Als algemene opmerking vooraf is het nuttig om erop te wijzen dat de gepresenteerde tabellen uitsluitend betrekking hebben op de aantallen respondenten die een vraag daadwerkelijk beantwoord hebben. Dit betekent dat degenen die een vraag niet hebben ingevuld bij de berekening van de totalen en percentages buiten beschouwing zijn gelaten. Het kan voorkomen dat de percentages door afronding niet altijd tot 100 optellen. Onder de tabellen staat, indien van toepassing, aangegeven of de verschillen die tussen de studierichtingen worden geconstateerd significant zijn. Dit is gebeurd met behulp van een chi-kwadraat toets, welke aangeeft in hoeverre de geobserveerde frequenties in een tabel afwijken van de frequenties die worden verwacht indien er geen samenhang is tussen de beide variabelen. De bijbehorende pwaarde geeft de kans aan dat de gevonden verschillen op toeval berusten.

In de opeenvolgende hoofdstukken worden de volgende onderwerpen behandeld. In hoofdstuk 2 wordt een beschrijving gegeven van enkele persoons- en kwalificatiekenmerken van de afgestudeerden. Hoofdstuk 3 behandelt de intrede op de arbeidsmarkt aan de hand van de maatschappelijke positie tijdens de eerste twaalf maanden na het afstuderen, de intredewerkloosheid en de eventuele baanmobiliteit. Het beroep dat men uitoefent, alsmede het bedrijf of de instelling waar men werkzaam is, komen aan bod in hoofdstuk 4 . In hoofdstuk 5 wordt een aantal kenmerken gepresenteerd van de functie die de oudstudenten circa één jaar na afstuderen vervullen. Deze functie wordt in dit rapport met 'huidige' functie aangeduid, waarmee dus steeds wordt gedoeld op de betaalde functie die men op het moment van enquêtering vervult. De aansluiting tussen de gevolgde studie en de huidige functie vormt het onderwerp van hoofdstuk 6 , waarbij wordt ingegaan op de voor de functie vereiste opleiding en het combineren van verder leren en betaald werken. In hoofdstuk 7 wordt ingegaan op eventuele ontwikkelingen in de arbeidsmarktpositie, die zich bij de vijf eerder genoemde cohorten hebben afgetekend. In hoofdstuk 8 worden de belangrijkste onderzoekresultaten samengevat. 


\section{Kenmerken van de respondenten}

\subsection{Geslacht en leeftijd}

In deze paragraaf worden de respondenten beschreven aan de hand van twee persoonskenmerken, namelijk het geslacht en de leeftijd in het jaar van afstuderen. De kwalificaties waarover zij vóór het afstuderen beschikken, komen in paragraaf 2.2 aan bod.

\section{Geslacht}

Cohort '92 bestaat voor meer dan de helft (63\%) uit vrouwen. In tabel 2.1 komt duidelijk naar voren dat het aandeel van vrouwen onder gezondheidswetenschappers duidelijk het hoogst is. Daarna volgen juristen die de dagopleiding hebben gevolgd en basisartsen. Alleen bij juristen van de avondopleiding en economen zijn vrouwen in de minderheid.

Tabel 2.1

Procentueel aandeel van vrouwelijke afgestudeerden, cohort '92 naar faculteit

\begin{tabular}{|c|c|c|c|c|c|c|}
\hline & \multirow[t]{2}{*}{$\mathrm{FdG}$} & \multirow[t]{2}{*}{ FdGW } & \multicolumn{2}{|c|}{$\mathrm{FdR}$} & \multirow[t]{2}{*}{ FdEW } & \multirow[t]{2}{*}{$\mathrm{RL}$} \\
\hline & & & dag & avond & & \\
\hline$\%$ vrouwen & 55 & 80 & 57 & 40 & 25 & 63 \\
\hline Totaal $n(=100 \%)$ & 62 & 313 & 108 & 15 & 105 & 603 \\
\hline
\end{tabular}

Chi-square $=109.0 ;$ d.f. $=4 ; p<0.01$

Leeftijd

De leeftijd op het moment van afstuderen is berekend als het verschil tussen het kalenderjaar van afstuderen en het geboortejaar. Deze leeftijd bedraagt bij cohort '92 gemiddeld 26,9 jaar (tabel 2.2). Economen en afgestudeerden van de dagopleiding Nederlands recht zijn gemiddeld jonger dan basisartsen en gezondheidswetenschappers. Dat basisartsen ouder zijn, hangt samen met hun twee jaar langere nominale studieduur. Dat gezondheidswetenschappers gemiddeld ouder zijn hangt samen met hun afwijkend vooropleidingstraject. Zij hebben veel vaker dan economen en afgestudeerden van de dagopleiding Nederlands recht een HBO-opleiding voltooid voordat zij aan de RL gaan studeren (zie tabel 2.3).

In 1991 is de eerste lichting studenten van de avondopleiding Nederlands recht afgestudeerd. De in 1984 gestarte avondopleiding heeft hetzelfde onderwijsprogramma als de dagopleiding Nederlands recht. In plaats van vier jaar bedraagt de totale studieduur echter zeven jaar. Het onderwijs wordt gegeven in de avonduren, wekelijks gemiddeld twee avonden. De opleiding is bedoeld voor mensen die vanwege een baan of andere reden niet in staat zijn om de dagopleiding Nederlands recht te volgen. Van de 123 in 1993 geënquêteerde juristen hebben er 15, ofwel 12\%, de zevenjarige avondopleiding Nederlands recht gevolgd. De gemiddelde leeftijd bij afstuderen van deze avondstudenten ligt met 35,2 jaar beduidend hoger dan bij degenen die de dagopleiding Nederlands recht hebben gevolgd, die bij afstuderen gemiddeld 25,9 jaar oud zijn. 


\begin{tabular}{lrrrrrrr} 
& FdG & FdGW & \multicolumn{3}{c}{ FdR } & FdEW & RL \\
\cline { 4 - 6 } & & & dag & avond & \\
\hline Gemiddelde leeftijd in jaren & 27,6 & 27,5 & 25,9 & 35,2 & 24,7 & 26,9 \\
Standaardafwijking in jaren & 3,2 & 5,8 & 5,5 & 5,6 & 1,6 & 5,3 \\
Totaal n & 62 & 313 & 108 & 15 & 105 & 603 \\
\hline
\end{tabular}

$F=18.0 ;$ d.f. $=4 ; p<0.01$

\subsection{Kwalificaties}

In deze paragraaf worden de kwalificaties besproken, die zijn behaald vóór of tijdens de studie. Het gaat hierbij om kwalificaties waarvan wordt verondersteld dat zij staan voor opgedane kennis, houdingen en vaardigheden, die het functioneren binnen arbeidsorganisaties en op de arbeidsmarkt beïnvloeden. Hierbij wordt onderscheid gemaakt naar formele en informele kwalificaties. Formele kwalificaties zijn kwalificaties die men in het reguliere onderwijs verwerft, terwijl informele kwalificaties kunnen worden opgedaan buiten het reguliere onderwijs, bijvoorbeeld in een werkkring of in een bestuurlijke functie.

\section{Vooropleiding}

Als eerste is nagegaan wat de hoogste met diploma voltooide vooropleiding is alvorens men aan de $\mathrm{RL}$ is gaan studeren. Hiervan geeft tabel 2.3 een beeld. Naar voren komt dat zo'n driekwart (74\%) van afstudeerjaargang '92 als hoogste vooropleiding WWO heeft gevolgd; $23 \%$ beschikt vóór aanvang van de opleiding aan de RL over een HBO-diploma. Met name afgestudeerden van de dagopleiding Nederlands recht, basisartsen en economen zijn in overgrote meerderheid vanuit het WWO naar de RL doorgestroomd. Van de gezondheidswetenschappers en avondstudenten Nederlands recht heeft een derde een HBO-diploma behaald voordat zij aan de RL zijn gaan studeren.

Tabel 2.3

Hoogste voltooide vooropleiding, cohort '92 naar faculteit (in \%)

\begin{tabular}{|c|c|c|c|c|c|c|}
\hline & \multirow[t]{2}{*}{ FdG } & \multirow[t]{2}{*}{ FdGW } & \multicolumn{2}{|c|}{$\mathrm{FdR}$} & \multirow[t]{2}{*}{ FdEW } & \multirow[t]{2}{*}{$\mathrm{RL}$} \\
\hline & & & dag & avond & & \\
\hline $\begin{array}{l}\text { WWO } \\
\text { HBO } \\
\text { Andere }\end{array}$ & $\begin{array}{r}90 \\
10 \\
0\end{array}$ & $\begin{array}{r}63 \\
34 \\
3\end{array}$ & $\begin{array}{r}92 \\
4 \\
4\end{array}$ & $\begin{array}{r}60 \\
33 \\
7\end{array}$ & $\begin{array}{r}82 \\
16 \\
2\end{array}$ & $\begin{array}{r}74 \\
23 \\
3\end{array}$ \\
\hline Totaal $n(=100 \%)$ & 59 & 296 & 104 & 15 & 104 & 578 \\
\hline
\end{tabular}

Chi-square $=55.5 ;$ d.f. $=8 ; p<0.01$

\section{Werkervaring}

Aan de afgestudeerden is gevraagd of men vóór of tijdens de studie aan de RL betaalde werkervaring (exclusief vakantie- of weekendwerk) heeft opgedaan. Hiervan geeft tabel 2.4 een beeld. In de tabel staat tevens vermeld om welk soort werkervaring het hierbij gaat. Van de in 1992 afgestudeerde oudstudenten blijkt meer dan de helft (58\%) vóór of tijdens de studie aan de RL betaalde werkervaring te hebben 
opgedaan. Vooral oudstudenten van de avondopleiding Nederlands recht en gezondheidswetenschappers hebben vóór het afstuderen vaak al betaald werk verricht.

Tabel 2.4

Procentueel aandeel van oudstudenten met betaalde werkervaring vóór afstuderen en soort werkervaring (in \%), cohort '92 naar faculteit

\begin{tabular}{|c|c|c|c|c|c|c|}
\hline & \multirow[t]{2}{*}{ FdG } & \multirow[t]{2}{*}{ FdGW } & \multicolumn{2}{|c|}{$\mathrm{FdR}$} & \multirow[t]{2}{*}{ FdEW } & \multirow[t]{2}{*}{$\mathrm{RL}$} \\
\hline & & & dag & avond & & \\
\hline$\%$ betaalde werkervaring & 47 & 63 & 53 & 93 & 52 & 58 \\
\hline $\begin{array}{l}\text { Totaal } n(=100 \%) \\
\text { Soort betaalde werkervaring }\end{array}$ & 62 & 313 & 108 & 15 & 105 & 603 \\
\hline $\begin{array}{l}\text { studentassistent } \\
\text { binnen eigen vakgebied } \\
\text { buiten eigen vakgebied }\end{array}$ & $\begin{array}{l}33 \\
33 \\
33\end{array}$ & $\begin{array}{l}32 \\
46 \\
22\end{array}$ & $\begin{array}{l}25 \\
23 \\
52\end{array}$ & $\begin{array}{r}0 \\
38 \\
62\end{array}$ & $\begin{array}{l}41 \\
28 \\
30\end{array}$ & $\begin{array}{l}31 \\
38 \\
31\end{array}$ \\
\hline
\end{tabular}

Chi-square $=16.6 ;$ d.f. $=4 ; p<0.01$

Wat de aard van de betaalde werkervaring betreft, komt in tabel 2.4 naar voren dat economen het vaakst als studentassistent betaalde werkervaring hebben opgedaan. Gezondheidswetenschappers beschikken het vaakst over betaalde werkervaring die zij anders dan als studentassistent maar wel binnen het 'eigen' vakgebied hebben opgedaan. Juristen hebben als enigen het vaakst betaalde werkervaring buiten het 'eigen' vakgebied opgedaan vóór het afstuderen aan de RL. Dit geldt zowel voor afgestudeerden van de dagopleiding als voor afgestudeerden van de avondopleiding.

\section{Bestuurlijke envaring}

Bijna de helft (45\%) van afstudeerjaargang '92 heeft vóór of tijdens de studie aan de RL enigerlei vorm van bestuurlijke ervaring opgedaan. Tabel 2.5 laat verder zien dat afgestudeerden van de economische en juridische studierichtingen vaker over bestuurlijke ervaring beschikken dan afgestudeerden van de medische en gezondheidswetenschappelijke studierichtingen.

Tabel 2.5

Procentueel aandeel van oudstudenten met bestuurlijke ervaring vóór afstuderen, cohort '92 naar faculteit

\begin{tabular}{lccccrrr} 
& FdG & FdGW & \multicolumn{3}{c}{ FdR } & FdEW & RL \\
\cline { 4 - 6 } & & & dag & avond & \\
\hline \% bestuurlijke ervaring & 42 & 38 & 57 & 60 & 53 & 45 \\
Totaal $n(=100 \%)$ & 62 & 313 & 108 & 15 & 105 & 603 \\
\hline
\end{tabular}

Chi-square $=18.0 ;$ d.f. $=4 ; p<0.01$

\subsection{Samenvatting}

Afstudeerjaargang '92 bestaat voor meer dan de helft uit vrouwen. Het procentuele aandeel van vrouwelijke afgestudeerden is het hoogst onder gezondheidswetenschappers en het laagst onder economen. De gemiddelde leeftijd bij afstuderen bedraagt 26,9 jaar. De afgestudeerden van de avondopleiding Nederlands recht zijn gemiddeld het oudst en economen het jongst. Driekwart van de afgestudeerden heeft als hoogste vooropleiding WWO gevolgd. Afgestudeerden van de dagopleiding Nederlands recht, 
basisartsen en economen zijn in overgrote meerderheid vanuit het VWO naar de RL doorgestroomd, terwijl gezondheidswetenschappers en avondstudenten Nederlands recht vaak vanuit het HBO zijn ingestroomd. Zes van iedere tien afgestudeerden heeft vóór of tijdens de studie aan de RL betaalde werkervaring opgedaan. Vooral oudstudenten van de avondopleiding Nederlands recht en gezondheidswetenschappers zijn vóór het afstuderen vaak al betaald werkzaam geweest. Bijna de helft van afstudeerjaargang ' 92 heeft vóór of tijdens de studie bestuurlijke ervaring opgedaan (juristen en economen vaker dan basisartsen en gezondheidswetenschappers). 


\section{Intrede op de arbeidsmarkt}

\subsection{Intredewerkloosheid}

In deze paragraaf wordt de duur van de intredewerkloosheid behandeld. In paragraaf 3.2 komt de eventuele baanmobiliteit aan bod, waaronder wordt verstaan het veranderen van werkgever en/of van functie. Vervolgens wordt in paragraaf 3.3 de huidige maatschappelijke positie geschetst, waarbij nader wordt ingegaan op de werkzoekenden en op degenen die additioneel 1e fase onderwijs volgen.

Tabel 3.1 geeft aan hoe lang men werkloos is geweest, voorafgaand aan de eerste betaalde baan na het afstuderen. De duur van de intredewerkloosheid, dit wil zeggen de tijdsduur die afgestudeerden werkloos zijn, voorafgaand aan hun eerste betaalde baan na het afstuderen, geeft een indicatie van de mate waarin de intrede op de arbeidsmarkt succesvol verloopt. Tabel 3.1 schetst de mate van succes waarmee de afgestudeerden van cohort '92 zich op de arbeidsmarkt hebben aangeboden. In deze tabel zijn uitsluitend werkloosheidsperioden begrepen die eindigen in de eerste betaalde baan na het afstuderen, alsmede werkloosheidsperioden die voortduren tot het moment van de enquête. Hierbij wordt een onderscheid gemaakt tussen oudstudenten die meteen, dit wil zeggen zonder voorafgaande werkloosheid, een betaalde baan hebben (de werkloosheidsduur bedraagt in dat geval 0 maanden), afgestudeerden die $1 \mathrm{t} / \mathrm{m} 3$ maanden werkloos zijn geweest voordat zij in de eerste betaalde baan starten, afgestudeerden die gedurende $4 \mathrm{t} / \mathrm{m} 6$ maanden werkloos waren, en afgestudeerden die meer dan een half jaar werkloos zijn (geweest).

Tabel 3.1

Duur intredewerkloosheid, cohort '92 naar faculteit (in \%)

\begin{tabular}{|c|c|c|c|c|c|c|}
\hline & \multirow[t]{2}{*}{ FdG } & \multirow[t]{2}{*}{ FdGW } & \multicolumn{2}{|c|}{ FdR } & \multirow[t]{2}{*}{ FdEW } & \multirow[t]{2}{*}{$\mathrm{RL}$} \\
\hline & & & dag & avond & & \\
\hline $\begin{array}{l}0 \text { maanden } \\
1-3 \text { maanden } \\
4-6 \text { maanden } \\
>6 \text { maanden }\end{array}$ & $\begin{array}{r}79 \\
21 \\
0 \\
0\end{array}$ & $\begin{array}{r}65 \\
18 \\
10 \\
7\end{array}$ & $\begin{array}{r}68 \\
9 \\
8 \\
15\end{array}$ & $\begin{array}{r}87 \\
13 \\
0 \\
0\end{array}$ & $\begin{array}{r}67 \\
15 \\
11 \\
8\end{array}$ & $\begin{array}{r}68 \\
16 \\
8 \\
7\end{array}$ \\
\hline Totaal $n(=100 \%)$ & 61 & 283 & 87 & 15 & 102 & 548 \\
\hline
\end{tabular}

Chi-square $=27.3 ;$ d.f. $=12 ; p<0.01$

In tabel 3.1 komt naar voren dat de meeste afgestudeerden (84\%) die zich op de arbeidsmarkt aanbieden, niet ( 0 maanden) of slechts kort (maximaal 3 maanden) werkloos zijn geweest voorafgaand aan hun eerste betaalde baan. Meer dan de helft $(68 \%)$ van alle afgestudeerden die zich op de arbeidsmarkt aanbieden, had al een baan tijdens de studie of vond na het afstuderen meteen een betaalde baan. Werkloosheidsperioden van meer dan een half jaar komen slechts weinig voor (bij $7 \%$ van de aanbieders op de arbeidsmarkt). Aangezien avondstudenten doorgaans al een baan hebben wanneer zij de avondopleiding volgen, is het niet verwonderlijk dat de overgrote meerderheid (87\%) van de avondstudenten Nederlands recht bij het afstuderen betaald werk hebben. Van de oud-avondstudenten Nederlands recht en de basisartsen is niemand langer dan drie maanden werkloos geweest.

\subsection{Baanmobiliteit}

Bij de arbeidsmobiliteit kan onderscheid worden gemaakt tussen het aantal werkgevers waarbij men heeft 
gewerkt (externe baanmobiliteit) en het aantal functies dat men heeft vervuld. Bij het laatste kan ook interne baanmobiliteit een rol spelen, dit wil zeggen verandering van functie bij dezelfde werkgever, bijvoorbeeld door promotie, overplaatsing of substantiële verandering van de inhoud van de werkzaamheden.

\section{Verandering van werkgever}

In tabel 3.3 zijn de enquêteresultaten weergegeven met betrekking tot de externe baanmobiliteit van cohort '92. De interne baanmobiliteit komt in tabel 3.4 aan bod. De betreffende vragen zijn alleen voorgelegd aan degenen die op het moment van enquêteren betaald werk verrichtten. Militaire dienst moest hierbij buiten beschouwing worden gelaten.

Tabel 3.3

Externe baanmobiliteit in het eerste jaar na afstuderen, cohort '92 naar faculteit (in \%)

\begin{tabular}{|c|c|c|c|c|c|c|}
\hline & \multirow[t]{2}{*}{ FdG } & \multirow[t]{2}{*}{ FdGW } & \multicolumn{2}{|c|}{$\mathrm{FdR}$} & \multirow[t]{2}{*}{ FdEW } & \multirow[t]{2}{*}{$\mathrm{RL}$} \\
\hline & & & dag & avond & & \\
\hline $\begin{array}{l}\text { Niet van werkgever veranderd } \\
1 x \text { van werkgever veranderd } \\
>=2 x \text { van werkgever veranderd }\end{array}$ & $\begin{array}{l}38 \\
38 \\
24\end{array}$ & $\begin{array}{r}68 \\
26 \\
5\end{array}$ & $\begin{array}{r}66 \\
31 \\
3\end{array}$ & $\begin{array}{r}79 \\
21 \\
0\end{array}$ & $\begin{array}{r}76 \\
16 \\
8\end{array}$ & $\begin{array}{r}66 \\
26 \\
8\end{array}$ \\
\hline Totaal $n(=100 \%)$ & 58 & 243 & 74 & 14 & 87 & 476 \\
\hline
\end{tabular}

Ruim de helft van cohort ' 92 is circa één jaar na het afstuderen nog steeds bij de eerste werkgever werkzaam. Van degenen die wel van werkgever zijn veranderd, hebben de meesten nog maar één keer van werkgever gewisseld. Dit is niet verwonderlijk, aangezien het gaat om ten tijde van de enquête nog recent afgestudeerden. Juristen die de avondopleiding Nederlands recht hebben gevolgd en economen zijn in arbeidsmarkttermen gesproken het minst mobiel. Dat oudstudenten van de avondopleiding Nederlands recht relatief weinig van werkgever veranderen, hangt wellicht samen met het feit dat een deel na het afstuderen dezelfde baan aanhoudt die men al tijdens de studie had. Bij economen houdt de relatief lage externe baanmobiliteit wellicht verband met het gegeven dat zij vaker dan gezondheidswetenschappers en juristen vanuit de verkregen baan een post-doctorale beroepsopleiding volgen (zie tabel 6.3) en daarom minder geneigd zijn om de baan vlug te verlaten (zie tabel 3.5). Basisartsen zijn in het eerste jaar na afstuderen relatief vaak van werkgever veranderd. Wellicht heeft een aantal van hen tijdelijk een baan geaccepteerd, die men verlaat zodra een medische opleidingsplaats wordt gevonden. Inderdaad blijkt bijna een derde (29\%) van de basisartsen, die op het moment van de enquête betaald werken, op zoek te zijn naar een medische opleidingsplaats. Op het volgen van post-doctoraal beroepsonderwijs zal in hoofdstuk 6 worden teruggekomen.

\section{Verandering van functie}

Zoals eerder is opgemerkt, kan arbeidsmobiliteit ook een verandering van functie bij dezelfde werkgever inhouden. Wat de interne baanmobiliteit betreft, komt in tabel 3.4 naar voren dat bijna een kwart van de betaald werkende afgestudeerden van cohort ' 92 bij de huidige werkgever al eens van functie is veranderd. Juristen die de avondopleiding hebben gevolgd, blijken vaker dan de andere afgestudeerden intern al eens van functie te zijn veranderd. Dit is niet verwonderlijk aangezien zij immers doorgaans al een baan op het moment van afstuderen hebben, na de opleiding zelden van werkgever veranderen en 
bijgevolg reeds langer dan anderen bij hun huidige werkgever werkzaam zijn. De helft van de oudavondstudenten Nederlands recht is dan ook na het afstuderen al eens intern van functie veranderd. Ter vergelijking: onder oudstudenten van de dagopleiding Nederlands recht bedraagt de interne baanmobiliteit $24 \%$.

Tabel 3.4

Interne baanmobiliteit in het eerste jaar na afstuderen, cohort '92 naar faculteit (in \%)

\begin{tabular}{|c|c|c|c|c|c|c|}
\hline & \multirow[t]{2}{*}{ FdG } & \multirow[t]{2}{*}{ FdGW } & \multicolumn{2}{|c|}{ FdR } & \multirow[t]{2}{*}{ FdEW } & \multirow[t]{2}{*}{$\mathrm{RL}$} \\
\hline & & & dag & avond & & \\
\hline $\begin{array}{l}\text { van functie veranderd } \\
\text { niet van functie veranderd }\end{array}$ & $\begin{array}{l}16 \\
84\end{array}$ & $\begin{array}{l}25 \\
75\end{array}$ & $\begin{array}{l}24 \\
76\end{array}$ & $\begin{array}{l}50 \\
50\end{array}$ & $\begin{array}{l}22 \\
78\end{array}$ & $\begin{array}{l}24 \\
76\end{array}$ \\
\hline Totaal $n(=100 \%)$ & 58 & 240 & 74 & 14 & 86 & 472 \\
\hline
\end{tabular}

Chi-square $=7.9 ;$ d.f. $=4 ; p=0.10$

\section{Potentiële baanmobiliteit}

Er zal nu worden ingegaan op de vraag hoe degenen die op het moment van enquêteren betaald werken (hetzij als hoofdbezigheid, hetzij als nevenactiviteit) hun baan beoordelen. Een indicatie hiervoor wordt gevormd door het al dan niet zoeken naar ander werk. Met betrekking tot betaald werkenden die op zoek zijn naar ander werk wordt, in arbeidsmarkttermen, gesproken van potentiële baanmobiliteit.

Tabel 3.5 schetst de omvang van de potentiële baanmobiliteit onder cohort '92. Hierin komt naar voren dat circa een kwart van de betaald werkenden op zoek is naar ander werk. Juristen die de avondopleiding hebben gevolgd en economen zijn minder vaak ander werk aan het zoeken dan afgestudeerden van andere opleidingen.

Tabel 3.5

Potentiële baanmobiliteit, circa een jaar na afstuderen, cohort '92 naar faculteit (in \%)

\begin{tabular}{|c|c|c|c|c|c|c|}
\hline & \multirow[t]{2}{*}{$\mathrm{FdG}$} & \multirow[t]{2}{*}{ FdGW } & \multicolumn{2}{|c|}{$\mathrm{FdR}$} & \multirow[t]{2}{*}{ FdEW } & \multirow[t]{2}{*}{$\mathrm{RL}$} \\
\hline & & & dag & avond & & \\
\hline $\begin{array}{l}\text { Zoekt andere baan } \\
\text { Zoekt niet andere baan }\end{array}$ & $\begin{array}{l}31 \\
69\end{array}$ & $\begin{array}{l}31 \\
69\end{array}$ & $\begin{array}{l}27 \\
73\end{array}$ & $\begin{array}{l}13 \\
87\end{array}$ & $\begin{array}{l}14 \\
86\end{array}$ & $\begin{array}{l}27 \\
73\end{array}$ \\
\hline Totaal $n(=100 \%)$ & 55 & 235 & 73 & 15 & 90 & 468 \\
\hline
\end{tabular}

Chi-square $=11.5 ;$ d.f. $=4 ; p<0.05$

\subsection{Maatschappelijke positie, circa één jaar na afstuderen}

In paragraaf 3.1 is een beeld geschetst van de duur van de intredewerkloosheid. In deze paragraaf komt de maatschappelijke positie aan bod die men op het moment van de enquête, dus een tot anderhalf jaar na het afstuderen, inneemt. Hierbij wordt in het bijzonder nagegaan hoeveel afgestudeerden dan werkloos zijn. Vervolgens wordt nader ingegaan op degenen die additioneel $1^{\mathrm{e}}$ fase onderwijs volgen. 
Tabel 3.6 laat zien dat de meerderheid (79\%) van afstudeerjaargang '92 op het moment van enquêteren (circa een jaar na het afstuderen) een betaalde baan voor tenminste twaalf uur per week heeft. In deze tabel staan tevens de hoofdbezigheden vermeld van degenen die niet, of minder dan 12 uur per week, betaald werken. In de hoofdstukken $4 \mathrm{t} / \mathrm{m} 6$ zal worden ingegaan op de kenmerken van het betaalde werk dat als hoofdbezigheid of als nevenactiviteit gedurende tenminste 12 uur per week wordt verricht.

In tabel 3.6 komt verder naar voren dat het procentuele aandeel van betaald werkenden onder gezondheidswetenschappers en afgestudeerden van de dagopleiding Nederlands recht lager is dan onder afgestudeerden van de andere opleidingen. Gezondheidswetenschappers en vooral ouddagstudenten Nederlands recht blijken relatief vaak nog op zoek te zijn naar een betaalde baan, of additioneel onderwijs te volgen. Hieronder wordt nader ingegaan op de afgestudeerden die op het moment van enquêteren werkloos zijn.

Tabel 3.6

Maatschappelijke positie, één jaar na afstuderen, cohort '92 naar faculteit (in \%)

\begin{tabular}{|c|c|c|c|c|c|c|}
\hline & \multirow[t]{2}{*}{ FdG } & \multirow[t]{2}{*}{ FdGW } & \multicolumn{2}{|c|}{ FdR } & \multirow[t]{2}{*}{ FdEW } & \multirow[t]{2}{*}{ RL } \\
\hline & & & dag & avond & & \\
\hline Betaald werk (>11 uur per week) & 97 & 75 & 69 & 100 & 86 & 79 \\
\hline Militaire dienst & 2 & 1 & 4 & 0 & 5 & 2 \\
\hline Full-time onderwijs & 0 & 9 & 12 & 0 & 2 & 7 \\
\hline Onbetaald werk & 0 & 2 & 0 & 0 & 1 & 1 \\
\hline Werkzoekend & 2 & $\overline{9}$ & 15 & 0 & 6 & 9 \\
\hline $\begin{array}{l}\text { (zonder betaald werk) } \\
\text { Andere situatie }\end{array}$ & 0 & 4 & 1 & 0 & 1 & 2 \\
\hline Totaal $n(=100 \%)$ & 62 & 313 & 108 & 15 & 105 & 603 \\
\hline
\end{tabular}

Chi-square $=48.8 ;$ d.f. $=20 ; p<0.01$

\section{Werkloosheid}

Afgestudeerden zijn werkloos indien zij aan de volgende vier voorwaarden voldoen:

- niet of minder dan 12 uur per week betaald werken;

- tenminste 12 uur per week betaald willen werken;

- binnen twee weken beschikbaar zijn voor een betaalde baan van tenminste 12 uur per week;

- ingeschreven staan bij het arbeidsbureau.

Aldus gedefinieerd, is $9 \%$ van de respondenten die tot de beroepsbevolking ${ }^{4}$ behoren op het moment van enquêteren, dit wil zeggen één tot anderhalf jaar na het afstuderen, werkloos.

Alle basisartsen en oud-avondstudenten Nederlands recht die zich op de arbeidsmarkt aanbieden, doen dit met goed gevolg: niemand van hen is werkloos. Bij de andere faculteiten variëren de werkloosheidspercentages onder afgestudeerden die tot de beroepsbevolking behoren, van $6 \%$ onder economen

4. Ex-cursisten behoren tot de beroepsbevolking indien tenminste aan één van de volgende drie voorwaarden is voldaan: - tenminste 12 uur per week betaald werken;

- militaire of vervangende dienst vervullen;

- op zoek zijn naar en beschikbaar zijn voor betaald werk voor tenminste 12 uur per week. 
en $10 \%$ onder gezondheidswetenschappers tot $14 \%$ onder juristen die de dagopleiding hebben gevolgd. Deelname aan additioneel $1^{e}$ fase onderwijs na het afstuderen

Aan de afgestudeerden is gevraagd of men op het moment van enquêteren een opleiding volgt of na het afstuderen verder onderwijs heeft gevolgd. Indien men meerdere opleidingen volgt of heeft gevolgd, werd men verzocht om het onderwijsniveau en de richting aan te geven van de opleiding met het grootste aantal studie-uren. Hieronder wordt nader ingegaan op het volgen van $1^{\mathrm{e}}$ fase onderwijs na het afstuderen.

Gebleken is dat $6 \%$ van cohort ' 92 gedurende langere of kortere tijd na het afstuderen additioneel $1^{\mathrm{e}}$ fase onderwijs volgt. Afgestudeerden van de dagopleiding Nederlands recht nemen vaker dan anderen deel aan additioneel $1^{\mathrm{e}}$ fase onderwijs: $14 \%$ van de oud-dagstudenten Nederlands recht volgde gedurende kortere of langere tijd na het afstuderen additioneel $1^{\mathrm{e}}$ fase onderwijs, tegen $7 \%$ van de oud-avondstudenten Nederlands recht, $7 \%$ van de gezondheidswetenschappers, $1 \%$ van de economen en niemand van de basisartsen. Van de 14 juristen die gedurende langere of kortere tijd additioneel $1^{\mathrm{e}}$ fase onderwijs volgden, hebben er 10 additioneel onderwijs in het recht gevolgd.

\subsection{Samenvatting}

Bij alle faculteiten kan worden geconstateerd dat de meeste afgestudeerden die zich op de arbeidsmarkt aanbieden niet of hoogstens 3 maanden werkloos zijn geweest, voorafgaand aan de eerste betaalde baan. Afgestudeerden van de avondopleiding Nederlands recht blijken het vaakst meteen na het afstuderen betaald werkzaam te zijn.

Op het moment van enquêtering, dus een tot anderhalf jaar na afstuderen, is $6 \%$ van de respondenten niet beschikbaar voor de arbeidsmarkt omdat men full-time additioneel onderwijs volgt. Afgestudeerden van de dagopleiding Nederlands recht volgen vaker dan anderen full-time additioneel onderwijs. Gebleken is dat $14 \%$ van hen gedurende kortere of langere tijd na het afstuderen additioneel $1^{\mathrm{e}}$ fase onderwijs volgt.

De werkloosheid onder afgestudeerden als percentage van degenen die tot de beroepsbevolking behoren, bedraagt op het moment van enquêtering $9 \%$. Alle basisartsen en oud-avondstudenten Nederlands recht die zich op de arbeidsmarkt aanbieden, doen dit met goed gevolg: niemand van hen is werkloos. De werkloosheidspercentages onder afgestudeerden van de andere faculteiten die tot de beroepsbevolking behoren, variëren van $6 \%$ onder economen en $10 \%$ onder gezondheidswetenschappers tot $14 \%$ onder juristen die de dagopleiding hebben gevolgd.

Ruim de helft (66\%) van de betaald werkenden is een tot anderhalf jaar na het afstuderen nog steeds bij de eerste werkgever werkzaam; bijna een kwart $(24 \%)$ is bij de huidige werkgever al eens van functie veranderd. Oud-avondstudenten Nederlands recht zijn niet alleen het vaakst nog steeds bij dezelfde werkgever werkzaam, maar ook het vaakst al eens van functie veranderd bij hun huidige werkgever. Bovendien zijn zij, samen met economen, minder vaak dan anderen op zoek naar een andere baan. 


\section{Branche en beroep}

\subsection{Werkorganisatie}

In deze paragraaf worden de organisaties waarin de afgestudeerden op het moment van enquêteren werken (al dan niet in combinatie met het volgen van een opleiding), getypeerd aan de hand van de branche ${ }^{5}$, de grootte en de lokatie.

\section{Branche}

Tabel 4.1

Belangrijkste branches, cohort '92 naar faculteit (in \%)

\begin{tabular}{|c|c|c|}
\hline FdG: & $\begin{array}{ll}- & \text { algemeen niet-academisch ziekenhuis } \\
- & \text { psychiatrische inrichting/kliniek } \\
- & \text { bedrijfsgeneeskundige dienst } \\
- & \text { universiteit }\end{array}$ & $\begin{array}{r}(59 \%) \\
(7 \%) \\
(5 \%) \\
(5 \%)\end{array}$ \\
\hline FdGW: & $\begin{array}{ll}- & \text { universiteit } \\
- & \text { medisch/verpleegkundige dienst, bijv. GGD } \\
- & \text { academisch ziekenhuis } \\
- & \text { algemeen niet-academisch ziekenhuis } \\
- & \text { verpleeghuis } \\
- & \text { geneesmiddelenindustrie } \\
- & \text { medisch samenwerkingsverband }\end{array}$ & $\begin{array}{r}(14 \%) \\
(13 \%) \\
(11 \%) \\
(8 \%) \\
(6 \%) \\
(5 \%) \\
(5 \%)\end{array}$ \\
\hline FdR: & $\begin{array}{ll}- & \text { algemeen overheidsbestuur, bijv. gemeente } \\
- & \text { universiteit } \\
- & \text { advocatenkantoor } \\
\text { - } & \text { levensverzekeringsmaatschappij/pensioenfonds }\end{array}$ & $\begin{array}{r}(35 \%) \\
(8 \%) \\
(16 \%) \\
(5 \%)\end{array}$ \\
\hline FdEW: & $\begin{array}{ll}- & \text { accountantskantoor } \\
- & \text { universiteit } \\
- & \text { bankwezen } \\
- & \text { algemeen overheidsbestuur, bijv. gemeente } \\
- & \text { industrie } \\
- & \text { schade-/ziekte-/ongevallenverzekeringsbedrijf }\end{array}$ & $\begin{array}{r}(23 \%) \\
(14 \%) \\
(13 \%) \\
(10 \%) \\
(9 \%) \\
(5 \%)\end{array}$ \\
\hline
\end{tabular}

Tabel 4.1 geeft per faculteit een overzicht van de belangrijkste branches waarin de afgestudeerden van cohort '92 werken. Als criterium geldt dat tenminste $5 \%$ van de afgestudeerden in de desbetreffende branche werkzaam zijn.

\section{Bedrijfsomvang}

In tabel 4.2 worden de betaald werkenden van cohort '92 verdeeld naar grootte van de werkorganisatie waarin men terecht komt. Het gaat hierbij om de grootte van de vestiging van het bedrijf of de instelling waar men werkt.

Ruim de helft van afstudeerjaargang '92 komt terecht in grote organisaties met meer dan honderd personeelsleden. Bijna een derde komt terecht in kleine werkorganisaties met minder dan vijftig personeelsleden. Middelgrote organisaties (50 tot 100 personeelsleden) zijn voor de werkgelegenheid het minst belangrijk.

5. De branche is op vier-digit ingedeeld volgens de Standaard Bedrijfsindeling van het CBS (CBS, 1982). Deze indeling is voor het eerst bij cohort ' 90 verder gedifferentieerd om waar nodig branches nader te kunnen onderscheiden. 


\begin{tabular}{|c|c|c|c|c|c|c|}
\hline & \multirow[t]{2}{*}{ FdG } & \multirow[t]{2}{*}{ FdGW } & \multicolumn{2}{|c|}{$\mathrm{FdR}$} & \multirow[t]{2}{*}{ FdEW } & \multirow[t]{2}{*}{$\mathrm{RL}$} \\
\hline & & & dag & avond & & \\
\hline $\begin{array}{l}1 \text { - } 9 \text { personen } \\
10-49 \text { personen } \\
50-99 \text { personen } \\
100 \text { of meer personen }\end{array}$ & $\begin{array}{r}11 \\
26 \\
5 \\
58\end{array}$ & $\begin{array}{r}8 \\
15 \\
14 \\
63\end{array}$ & $\begin{array}{l}20 \\
20 \\
11 \\
49\end{array}$ & $\begin{array}{r}8 \\
31 \\
0 \\
62\end{array}$ & $\begin{array}{r}8 \\
26 \\
13 \\
53\end{array}$ & $\begin{array}{l}10 \\
20 \\
12 \\
58\end{array}$ \\
\hline Totaal $n(=100 \%)$ & 57 & 225 & 71 & 13 & 86 & 452 \\
\hline
\end{tabular}

Chi-square $=19.8 ;$ d.f. $=12 ; p=0.07$

\section{Lokatie}

In tabel 4.3 komt naar voren dat vrijwel alle betaald werkende afgestudeerden in Nederland werken; 'slechts' $3 \%$ komt in het buitenland terecht. Dat oudstudenten van de FdR nauwelijks of niet in het buitenland werken, is niet verwonderlijk aangezien het gaat om afgestudeerden in het Nederlands recht. Een op iedere twintig economen werkt in een ander land van de EG. Oud-avondstudenten Nederlands recht komen als enigen in meerderheid terecht op de regionale arbeidsmarkt.

Tabel 4.3

Werkregio, cohort '92 naar faculteit (in \%)

\begin{tabular}{|c|c|c|c|c|c|c|}
\hline & \multirow[t]{2}{*}{ FdG } & \multirow[t]{2}{*}{ FdGW } & \multicolumn{2}{|c|}{$\mathrm{FdR}$} & \multirow[t]{2}{*}{ FdEW } & \multirow[t]{2}{*}{$\mathrm{RL}$} \\
\hline & & & dag & avond & & \\
\hline $\begin{array}{l}\text { binnen EG (excl. NL) } \\
\text { buiten EG } \\
\text { Nederland (excl. Z-Limburg) } \\
\text { Zuid-Limburg }\end{array}$ & $\begin{array}{r}0 \\
0 \\
67 \\
33\end{array}$ & $\begin{array}{r}1 \\
1 \\
69 \\
28\end{array}$ & $\begin{array}{r}0 \\
2 \\
65 \\
33\end{array}$ & $\begin{array}{r}0 \\
0 \\
38 \\
62\end{array}$ & $\begin{array}{r}6 \\
0 \\
65 \\
29\end{array}$ & $\begin{array}{r}2 \\
1 \\
67 \\
31\end{array}$ \\
\hline Totaal $n(=100 \%)$ & 55 & 212 & 63 & 13 & 84 & 427 \\
\hline
\end{tabular}

Chi-square $=21.1 ;$ d.f. $=12 ; p<0.05$

\subsection{Beroep}

In deze paragraaf wordt ingegaan op de beroepen van de betaald werkende afgestudeerden van de onderscheiden studierichtingen ${ }^{6}$.

Nieuwe functies

Voordat wordt ingegaan op de beroepen van de in 1992 afgestudeerde basisartsen, gezondheidswetenschappers, juristen en economen, wordt eerst aangegeven in hoeverre zij nieuwe functies binnen werkorganisaties bekleden. Wanneer afgestudeerden instromen in nieuwe functies binnen werkorganisaties, wijst dit op een uitbreiding van de werkgelegenheid voor de desbetreffende categorie afgestudeer-

6. Voor de indeling van de beroepen is in eerste instantie gebruik gemaakt van de beroepenclassificatie van het CBS (CBS, 1984). Waar nodig zijn codes toegevoegd om beroepen nader te kunnen onderscheiden. 
den in deze organisaties. Instroom in bestaande functies vormt een indicatie voor de vervanging van vertrekkend personeel, in verband met vervroegde uittreding, pensionering e.d.

Tabel 4.5

Procentueel aandeel van nieuwe functies, cohort '92 naar faculteit

\begin{tabular}{|c|c|c|c|c|c|c|}
\hline & \multirow[t]{2}{*}{ FdG } & \multirow[t]{2}{*}{ FdGW } & \multicolumn{2}{|c|}{ FdR } & \multirow[t]{2}{*}{ FdEW } & \multirow[t]{2}{*}{$\mathrm{RL}$} \\
\hline & & & dag & avond & & \\
\hline$\%$ nieuwe functies & 7 & 26 & 14 & 21 & 19 & 21 \\
\hline Totaal $n(=100 \%)$ & 58 & 227 & 69 & 14 & 85 & 453 \\
\hline
\end{tabular}

Chi-square $=13.2 ;$ d.f. $=4 ; p<0.05$

Tabel 4.5 laat zien dat de meeste afgestudeerden van cohort '92 bestaande functies innemen, waarbij gezondheidswetenschappers iets vaker dan de andere afgestudeerden ook nieuwe functies bekleden.Er is ook nagegaan of nieuwe functies qua vereist opleidingsniveau verschillen van bestaande functies. Dit blijkt niet het geval te zijn (Chi-square $=0.3$; d.f. $=1 ; p=0.59$ ).

Gebleken is dat het bij nieuwe functies even vaak als bij bestaande functies om academische functies gaat, dit wil zeggen om functies waarvoor volgens de respondenten minimaal een universitaire opleiding is vereist ${ }^{7}$. In paragraaf 6.1 zal nader worden ingegaan op het opleidingsniveau dat minimaal voor de functie is vereist.

Tabel 4.6

Belangrijkste beroepen, cohort '92 naar faculteit (in \%)

\begin{tabular}{|c|c|c|}
\hline FdG: & $\begin{array}{l}\text { - } \text { arts-assistent in ziekenhuis e.d. } \\
\text { - } \quad \text { keurings-/verzekeringsarts } \\
\text { - } \text { medisch-wetenschappelijk onderzoeker }\end{array}$ & $\begin{array}{r}(66 \%) \\
(7 \%) \\
(5 \%)\end{array}$ \\
\hline FdGW: & 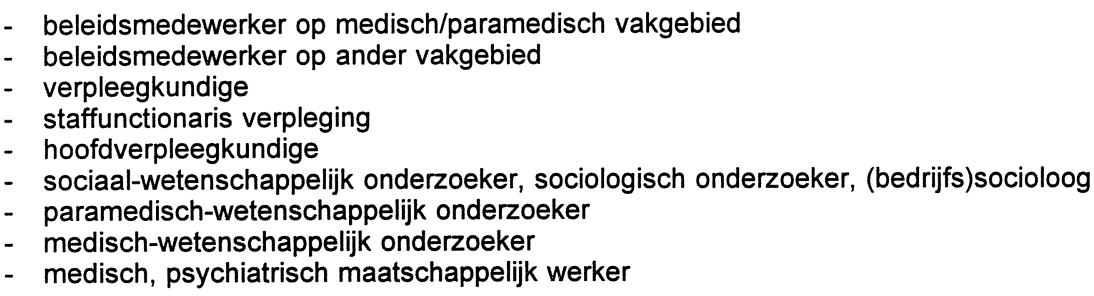 & $\begin{array}{r}11 \%) \\
(5 \%) \\
(10 \%) \\
(8 \%) \\
(7 \%) \\
(9 \%) \\
(6 \%) \\
(5 \%) \\
(5 \%)\end{array}$ \\
\hline FdR: & $\begin{array}{ll}- & \text { juridisch medewerker } \\
- & \text { advocaat } \\
- & \text { juridisch adviseur } \\
- & \text { beleidsmedewerker op juridisch vakgebied } \\
- & \text { juridisch wetenschappelijk medewerker } \\
- & \text { niet-uitvoerend (hoofd)ambtenaar }\end{array}$ & $\begin{array}{r}(24 \%) \\
(17 \%) \\
(8 \%) \\
(6 \%) \\
(6 \%) \\
(5 \%)\end{array}$ \\
\hline FdEW: & $\begin{array}{l}\text { - economist, (bedrijfs)econoom, sociaal-economisch onderzoeker } \\
\text { - } \text { assistent-accountant } \\
\text { - } \text { (bedrijfs)accountant } \\
\text { - beleidsmedewerker op economisch vakgebied } \\
\text { - hogere of middelbare employé } \\
\text { - } \text { marketing-specialist/-assistent } \\
\text { - } \text { docent (bedrijfs)economie }\end{array}$ & $\begin{array}{r}(14 \%) \\
(14 \%) \\
(14 \%) \\
(9 \%) \\
(8 \%) \\
(7 \%) \\
(7 \%) \\
(8 \%)\end{array}$ \\
\hline
\end{tabular}

7. Chi-kwadraat $=3.6$; d.f. $=1 ; p=0.06$. 


\section{Beroep}

Tabel 4.6 geeft een overzicht van de meest frequent uitgeoefende beroepen van basisartsen, gezondheidswetenschappers, juristen en economen. Hierbij worden alle beroepen vermeld waarin $5 \%$ of meer van de afgestudeerden van een faculteit werkzaam is. Uiteraard tellen de percentages hierdoor niet noodzakelijkerwijs op tot 100 . In deze tabel zijn ook de beroepen opgenomen van degenen die betaaldwerken combineren met het volgen van een beroepsopleiding, zoals bijvoorbeeld AIO's/OIO's, AGIO's, accountants in opleiding.

\subsection{Samenvatting}

Voor basisartsen zijn algemene, niet-academische ziekenhuizen (59\%) de belangrijkste bron van werkgelegenheid; voor gezondheidswetenschappers zijn dit de universiteiten (14\%) en medisch/verpleegkundige diensten (13\%). Voor juristen zijn algemene overheidsbesturen de belangrijkste werkgevers (35\%). Veel economen zijn bij accountantskantoren gaan werken (23\%). Vergeleken met andere afgestudeerden zijn basisartsen in een smalle 'range' van bedrijfsgroepen werkzaam. Bovendien hebben basisartsen een nauw afgebakend beroependomein.

Ruim de helft van de afgestudeerden werkt in grote organisaties met meer dan honderd personeelsleden (58\%).

Vrijwel alle afgestudeerden komen terecht op de Nederlandse arbeidsmarkt; juristen die de avondopleiding hebben gevolgd bovendien in meerderheid op de regionale arbeidsmarkt. Van de betaald werkende afgestudeerden werkt $3 \%$ in het buitenland. Economen zijn vaker dan andere afgestudeerden van de $\mathrm{RL}$ in het buitenland werkzaam, namelijk in andere EG-landen.

De meerderheid van afstudeercohort '92 neemt bestaande functies binnen werkorganisaties in ( $80 \%$ ). Gezondheidswetenschappers bekleden iets vaker dan anderen ook nieuwe functies. 


\section{Functiekenmerken}

\subsection{Functieverwerving}

In dit hoofdstuk wordt ingegaan op de betaalde functies waarin de oudstudenten werkzaam zijn op het moment van enquêteren, dus circa een jaar na het afstuderen. Eerst wordt nagegaan op welke wijze men de functie heeft verkregen. Vervolgens worden de functies getypeerd aan de hand van het soort dienstverband dat men is aangegaan, de duur van de aanstelling die men heeft en het aantal uren per week dat men werkt. Tenslotte wordt nagegaan of men binnen de werkorganisatie leiddinggevend werkzaam is en hoeveel men verdient.

Deze paragraaf beschrijft de kanalen waarlangs men de eerste betaalde baan na het afstuderen heeft verkregen. Het gaat hierbij om degenen die op het moment van de enquête nog steeds bij de eerste werkgever, dus in hun intredebaan werkzaam zijn. Het kanaal waarlangs men de functie bij de eerste werkgever heeft verkregen is weergegeven in tabel 5.1.

Tabel 5.1

Verwervingskanaal intredebaan, cohort '92 naar faculteit (in \%)

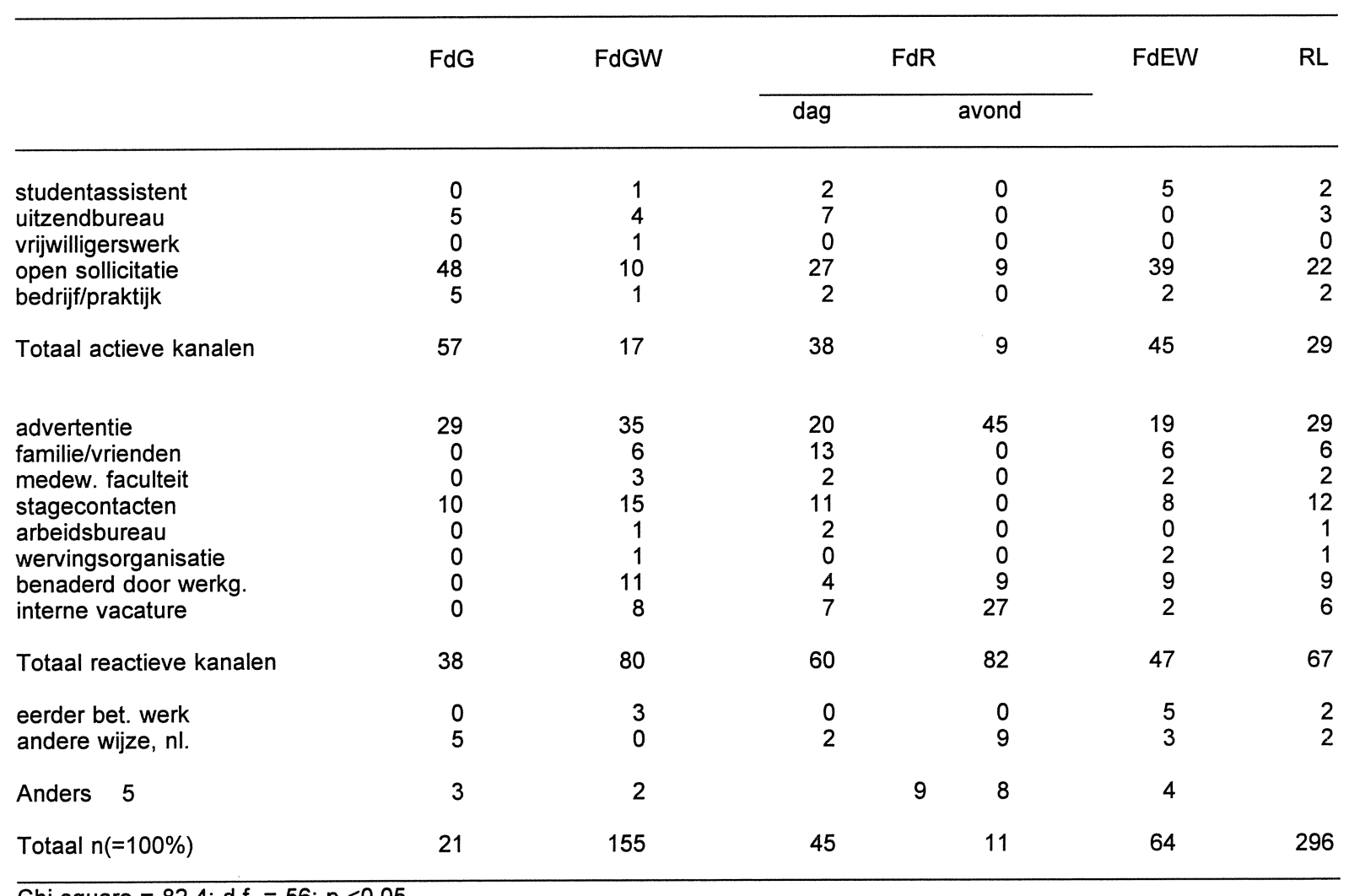

Chi-square $=82.4 ;$ d.f. $=56 ; p<0.05$

Reageren op een advertentie (29\%), ongevraagd ('open') solliciteren (22\%) en stage-contacten (12\%) vormen de drie belangrijkste kanalen waarmee de afgestudeerden van cohort '92 hun intredebaan hebben verkregen. Advertenties zijn met name voor afgestudeerden van de dagopleiding Nederlands recht van belang geweest, en open sollicitaties vooral voor basisartsen en economen. Stagecontacten blijken relatief belangrijk te zijn geweest voor gezondheidswetenschappers. Oudstudenten van de avondopleiding Nederlands recht hebben de baan ook relatief vaak via interne vacatures verkregen. Dit is 
niet verwonderlijk omdat zij, zoals eerder naar voren is gekomen, doorgaans langer dan andere afgestudeerden bij hun huidige werkgever werkzaam zijn en in meerderheid na het afstuderen al eens bij deze werkgever van functie zijn veranderd.

Gezien vanuit de houding van de baanzoeker kunnen de kanalen waarlangs men de baan heeft verkregen globaal in twee categorieën worden ingedeeld. Aan de ene kant 'actieve' kanalen. Deze resulteren uit meer of minder vrijwillig verrichte activiteiten (studentassistentschap, inschakeling van een uitzendbureau) of uit initiatieven van de baanzoeker (vrijwilligerswerk, ongevraagd solliciteren en het zelf opzetten van een bedrijf of praktijk). Aan de andere kant 'reactieve' kanalen. Deze resulteren uit meer of minder verplichte activiteiten (stage, inschrijving bij een arbeidsbureau) of uit initiatieven of relationele netwerken van derden, zoals het geval is bij het reageren op advertenties, het zoeken via familie/vrienden of medewerkers van de RL en de benadering door wervingsbureaus of door werkgevers. Welnu, bij cohort '92 blijkt ruim een kwart (29\%) van de intredebanen via 'actieve' kanalen te zijn verkregen. Basisartsen, economen en afgestudeerden van de dagopleiding Nederlands recht hebben hun baan vaker via actieve kanalen gekregen dan juristen die de avondopleiding hebben gevolgd en gezondheidswetenschappers.

Hierboven zijn de kanalen waarlangs intredebanen worden verkregen op basis van de houding van de baanzoeker ingedeeld in 'actieve' en in 'reactieve' kanalen. De zoekkanalen kunnen ook worden ingedeeld door na te gaan of persoonlijke netwerken al dan niet van belang zijn geweest voor het verkrijgen van de baan. Van persoonlijke netwerken is sprake wanneer de baan is verkregen via familie/vrienden, medewerkers van de faculteit, stagecontacten, danwel uit vroeger verricht werk als studentassistent of als vrijwilliger. Gebleken is dat bij afstudeercohort '92 een kwart van de intredebanen via persoonlijke netwerken is verkregen. Dit varieert van $0 \%$ bij oud-avondstudenten Nederlands recht en $9 \%$ bij basisartsen tot $25 \%$ bij economen, $28 \%$ bij gezondheidswetenschappers en $29 \%$ bij juristen die de dagopleiding hebben gevolgd.

\subsection{Dienstverband en aanstelling}

\section{Dienstverband}

Aan de respondenten is gevraagd in wat voor dienstverband men thans werkt. In tabel $5.2 \mathrm{komt}$ naar voren dat vrijwel alle (96\%) betaald werkende afgestudeerden in loondienst werkt. Hierbij doen zich geen significante verschillen tussen de opleidingen voor.

Tabel 5.2

Procentueel aandeel van functies in loondienst circa één jaar na afstuderen, cohort ' 92 naar faculteit

\begin{tabular}{|c|c|c|c|c|c|c|}
\hline & \multirow[t]{2}{*}{ FdG } & \multirow[t]{2}{*}{ FdGW } & \multicolumn{2}{|c|}{ FdR } & \multirow[t]{2}{*}{ FdEW } & \multirow[t]{2}{*}{$\mathrm{RL}$} \\
\hline & & & dag & avond & & \\
\hline$\%$ loondienst & 96 & 96 & 93 & 100 & 95 & 96 \\
\hline Totaal $n(=100 \%)$ & 55 & 230 & 70 & 14 & 87 & 456 \\
\hline
\end{tabular}

Chi-square $=2.1 ;$ d.f. $=4 ; p=0.71$

Aanstelling

Aan de respondenten die in loondienst werken, is tevens gevraagd naar de soort aanstelling die men 
heeft. Tabel 5.3 geeft voor cohort ' 92 een indicatie van het vaste of tijdelijke karakter van de arbeidsovereenkomst, en daarmee van de arbeidszekerheid. Circa één jaar na afstuderen kan worden geconstateerd dat de meeste in loondienst werkende afgestudeerden vooralsnog een tijdelijke aanstelling hebben $(58 \%)$. Basisartsen hebben vaker dan anderen tijdelijke aanstellingen, in het bijzonder aanstellingen voor langer dan één jaar. Dit houdt wellicht verband met het gegeven dat een aantal basisartsen in een per definitie meerjarige, doch tijdelijke medische opleidingsplaats werkt (zie tabel 6.3). De overgrote meerderheid van de oud-avondstudenten Nederlands recht heeft een vaste aanstelling.

Tabel 5.3

Soort aanstelling circa één jaar na afstuderen, cohort '92 naar faculteit (in \%)

\begin{tabular}{|c|c|c|c|c|c|c|}
\hline & \multirow[t]{2}{*}{$\mathrm{FdG}$} & \multirow[t]{2}{*}{ FdGW } & \multicolumn{2}{|c|}{$\mathrm{FdR}$} & \multirow[t]{2}{*}{ FdEW } & \multirow[t]{2}{*}{$\mathrm{RL}$} \\
\hline & & & dag & avond & & \\
\hline $\begin{array}{l}\text { Tijdelijk, }=<1 \text { jaar } \\
\text { Tijdelijk, }>1 \text { jaar } \\
\text { Vast }\end{array}$ & $\begin{array}{l}36 \\
53 \\
11\end{array}$ & $\begin{array}{l}29 \\
25 \\
47\end{array}$ & $\begin{array}{l}29 \\
36 \\
35\end{array}$ & $\begin{array}{r}0 \\
14 \\
86\end{array}$ & $\begin{array}{l}32 \\
17 \\
51\end{array}$ & $\begin{array}{l}29 \\
28 \\
42\end{array}$ \\
\hline Totaal $n(=100 \%)$ & 55 & 219 & 66 & 14 & 77 & 431 \\
\hline
\end{tabular}

Chi-square $=46.1 ;$ d.f. $=8 ; p<0.01$

\section{Arbeidsduur}

De contractuele wekelijkse arbeidsduur is een aspect van de aanstelling dat een indicatie biedt voor de mate van arbeidsparticipatie. Tabel 5.4 geeft voor cohort ' 92 een overzicht van het gemiddeld aantal uren dat men contractueel per week in loondienst werkt. In de tabel komt naar voren dat basisartsen langere werkweken en gezondheidswetenschappers kortere werkwerken hebben dan juristen en economen, die hierbij een middenpositie innemen. Contractueel werken mannen over het geheel genomen 2,1 uur per week langer dan vrouwen.

\section{Tabel 5.4}

Gemiddeld aantal uren dat men circa één jaar na afstuderen contractueel per week werkt, cohort '92 naar faculteit en geslacht

\begin{tabular}{lcccccc}
\hline & FdG & FdGW & \multicolumn{2}{c}{ FdR } & FdEW & RL \\
\cline { 4 - 6 } & & & dag & avond & \\
\hline Gemiddeld aantal uren, totaal & 40,8 & 35,1 & 37,2 & 36,9 & 38,3 & 36,8 \\
Gemiddeld aantal uren, mannen & 41,1 & 35,9 & 38,2 & 38,4 & 38,4 & 38,1 \\
Gemiddeld aantal uren, vrouwen & 40,5 & 34,9 & 6,5 & 34,0 & 37,9 & 36,0 \\
\hline
\end{tabular}

$\mathrm{F}=15.5 ;$ d.f. $=3 ; \mathrm{p}<0.01$ (verschillen tussen faculteiten)

$F=11.0 ;$ d.f. $=1 ; p<0.01$ (verschillen tussen mannen en vrouwen)

Een overzicht van het procentuele aandeel van full-time banen wordt gegeven in tabel 5.5. Onder een full-time baan wordt hier verstaan een baan waarin men contractueel meer dan 34 uur per week in loondienst werkzaam is. De tabel laat zien dat de meeste $(78 \%)$ betaald werkende oudstudenten van cohort '92 full-time banen hebben. Gezondheidswetenschappers werken vaker dan afgestudeerden van andere faculteiten in deeltijdbanen. Verder kan kan worden geconstateerd dat onder juristen en gezondheidswetenschappers mannen vaker in voltijd banen werken dan vrouwen. 
Tabel 5.5

Procentueel aandeel van full-time banen circa één jaar na afstuderen, cohort '92 naar faculteit en geslacht

\begin{tabular}{|c|c|c|c|c|c|c|}
\hline & \multirow[t]{2}{*}{ FdG } & \multirow[t]{2}{*}{ FdGW } & \multicolumn{2}{|c|}{$\mathrm{FdR}$} & \multirow[t]{2}{*}{ FdEW } & \multirow[t]{2}{*}{$\mathrm{RL}$} \\
\hline & & & dag & avond & & \\
\hline$\%$ full-time banen: totaal & 98 & 68 & 81 & 83 & 87 & 77 \\
\hline $\begin{array}{l}\% \text { full-time banen: mannen } \\
\% \text { full-time banen: vrouwen }\end{array}$ & $\begin{array}{r}100 \\
97\end{array}$ & $\begin{array}{l}75 \\
66\end{array}$ & $\begin{array}{l}88 \\
76\end{array}$ & $\begin{array}{r}100 \\
50\end{array}$ & $\begin{array}{l}86 \\
87\end{array}$ & $\begin{array}{l}86 \\
72\end{array}$ \\
\hline
\end{tabular}

Chi-square $=28.9 ;$ d.f. $=3 ; p<0.01$ (verschillen tussen faculteiten)

Chi-square $=11.0 ;$ d.f. $=1 ; p<0.01$ (verschillen tussen mannen en vrouwen)

\subsection{Leidinggeven en inkomen}

In deze paragraaf wordt eerst nagegaan of men een leidinggevende functie uitoefent. Vervolgens komt de hoogte van het genoten inkomen aan bod.

\section{Leidinggeven}

Aan de respondenten is gevraagd of men een leidinggevende functie heeft en, zo ja, aan hoeveel mensen men leiding geeft. Het antwoord op deze vraag geeft een indicatie van de mate waarin men leiding geeft, variërend van 'geen leidinggevende functie' tot 'leiding aan 50 of meer personen'. De antwoorden op deze vraag geven geen beeld van het niveau waarop leiding wordt gegeven, dit wil zeggen van de opleidingsniveaus van de mensen waaraan men leiding geeft.

Tabel 5.6 geeft een beeld van de mate waarin afgestudeerden van cohort '92 in leidinggevende functies werkzaam zijn. Naar voren komt dat de meesten $(79 \%)$ nog geen leidinggevende functie uitoefenen. Dit is niet verwonderlijk omdat deze populatie afgestudeerden nog aan het begin van de beroepscarrière staat. Oudstudenten van de avondopleiding Nederlands recht, economen en gezondheidswetenschappers hebben vaker leidinggevende functies dan juristen die de dagopleiding hebben gevolgd en basisartsen. De oud-avondstudenten Nederlands recht, die doorgaans ouder zijn, langere werkervaring hebben en bij hun werkgever al eens van functie zijn veranderd, zijn vaker dan de andere afgestudeerden doorgegroeid naar leidinggevende functies waarbij aan meer dan vier personen leiding wordt gegeven. Ook is naar voren gekomen dat mannen significant vaker dan vrouwen leidinggevende functies bekleden ${ }^{8}$. Van de in 1992 afgestudeerde mannen die betaalde arbeid verrichten, heeft $27 \%$ een leidinggevende functie. Bij de vrouwen is dit $18 \%$.

\section{Inkomen uit arbeid}

Tabel 5.7 geeft een beeld van het inkomen uit betaalde arbeid van basisartsen, gezondheidswetenschappers, juristen en economen, die in 1992 zijn afgestudeerd. Het gaat hierbij om het voor het aantal wekelijkse arbeidsuren gecorrigeerde inkomen. Dit om een vertekening als gevolg van de in tabel 5.4 geconstateerde verschillen in de lengte van de werkweek te voorkomen. Volledigheidshalve wordt er op gewezen dat het in tabel 5.7 gaat om het inkomen uit de hoofdfunctie van de respondent.

8. Chi-square $=4.1 ;$ d.f. $=1 ; p<0.05$. 


\begin{tabular}{|c|c|c|c|c|c|c|}
\hline & \multirow[t]{2}{*}{ FdG } & \multirow[t]{2}{*}{ FdGW } & \multicolumn{2}{|c|}{$\mathrm{FdR}$} & \multirow[t]{2}{*}{ FdEW } & \multirow[t]{2}{*}{$\mathrm{RL}$} \\
\hline & & & dag & avond & & \\
\hline $\begin{array}{l}\text { Geen leidinggevende functie } \\
\text { Leiding aan } 1-4 \text { personen } \\
\text { Leiding aan }>4 \text { personen }\end{array}$ & $\begin{array}{r}84 \% \\
9 \% \\
7 \%\end{array}$ & $\begin{array}{l}77 \% \\
10 \% \\
13 \%\end{array}$ & $\begin{array}{r}89 \% \\
11 \% \\
0 \%\end{array}$ & $\begin{array}{r}71 \% \\
7 \% \\
21 \%\end{array}$ & $\begin{array}{r}71 \% \\
23 \% \\
6 \%\end{array}$ & $\begin{array}{r}79 \% \\
12 \% \\
9 \%\end{array}$ \\
\hline Totaal $n(=100 \%)$ & 58 & 228 & 70 & 14 & 84 & 454 \\
\hline
\end{tabular}

Het gecorrigeerde inkomen is berekend door het totale bruto maandinkomen minus de toeslagen te delen door het aantal uren dat men contractueel per week werkt, en vervolgens met 40 te vermenigvuldigen ${ }^{9}$. Dit naar een veertigurige werkweek omgerekende inkomen reflecteert de inkomensverschillen per uur. Deze berekeningswijze van het bruto maandinkomen bij een veertigurige werkweek leidde bij één respondent tot een onrealistisch laag maandinkomen (minder dan fl. 1.000,- bruto) en bij vier respondenten tot extreem hoge maandinkomens (meer dan fl. 10.000,- bruto). Deze vijf extreme inkomenswaarden zijn bij de berekening van de in tabel 5.7 vermelde gemiddelden niet meegenomen, aangezien zij een te zware wissel zouden trekken op de gemiddelde waarden.

Tabel 5.7

Gemiddeld bruto maandinkomen bij een 40-urige werkweek circa één jaar na afstuderen, cohort '92 naar faculteit en geslacht

\begin{tabular}{lrrrrrrr}
\hline & \multirow{2}{*}{ FdG } & FdGW & \multicolumn{3}{c}{ FdR } & \multirow{2}{*}{ FdEW } & RL \\
\cline { 5 - 6 } & & & dag & avond & \\
\hline Gemiddeld inkomen, totaal & 4956 & 4076 & 3388 & 5304 & 3868 & 4077 \\
Totaal n & 53 & 195 & 63 & 11 & 79 & 401 \\
Gemiddeld inkomen, mannen & 5060 & 4649 & 3460 & 5129 & 3881 & 4252 \\
Gemiddeld inkomen, vrouwen & 4875 & 3924 & 3341 & 5611 & 3836 & 3969 \\
\hline
\end{tabular}

$F=18.1 ;$ d.f. $=4 ; p<0.01$ (verschillen tussen faculteiten)

$F=5.2 ;$ d.f. $=1 ; p<0.05$ (verschillen tussen mannen en vrouwen)

Circa één jaar na het afstuderen bedraagt het bruto maandinkomen bij een veertigurige werkweek onder betaald werkende afgestudeerden van cohort '92 gemiddeld fl 4.007,-. Juristen die de avondopleiding hebben gevolgd en basisartsen verwerven gemiddeld de hoogste inkomens. Verder komt in tabel 5.7 naar voren dat over de totale populatie genomen, mannen significant meer verdienen dan vrouwen. Het verschil in bruto maandinkomen bij een veertigurige werkweek tussen beide sexen bedraagt fl 283,- . Vooral bij gezondheidswetenschappers kan worden geconstateerd dat mannen meer verdienen dan vrouwen. Echter, bij juristen die de avondopleiding hebben gevolgd zijn het de vrouwen die gemiddeld het meest verdienen.

9. Deze omrekening van het inkomen naar een veertigurige werkweek leidt bij basisartsen, vanwege hun groot aantal wekelijkse arbeidsuren tot een onderschatting van hun inkomen. 


\subsection{Samenvatting}

Reageren op een advertentie (29\%), ongevraagd ('open') solliciteren (22\%) en stage-contacten (12\%) vormen de drie belangrijkste kanalen waarmee afgestudeerden hun intredebaan verkrijgen. Advertenties zijn met name voor oudstudenten van de dagopleiding Nederlands recht van belang, en open sollicitaties vooral voor basisartsen en economen. Stagecontacten blijken belangrijker te zijn voor gezondheidswetenschappers dan voor andere afgestudeerden.

Vrijwel alle betaald werkenden (96\%) werken in loondienst. Ruim de helft (58\%) van de in loondienst werkende afgestudeerden heeft een tijdelijke aanstelling. Basisartsen hebben vaker dan anderen tijdelijke aanstellingen, in het bijzonder aanstellingen voor langer dan een jaar. Oud-avondstudenten Nederlands recht zijn in overgrote meerderheid in vaste banen werkzaam. De meeste $(78 \%)$ betaald werkende oudstudenten hebben een full-time baan. Gezondheidswetenschappers werken vaker dan anderen ook in deeltijdbanen. Basisartsen hebben de langste werkweken. Gezondheidswetenschappers werken gemiddeld het kortst.

Circa een jaar na het afstuderen oefent de meerderheid (79\%) van de betaald werkende afgestudeerden nog geen leidinggevende functie uit. Het bruto maandinkomen bij een veertigurige werkweek bedraagt circa een jaar na het afstuderen gemiddeld fl 4.007,-- Tussen de afzonderlijke studierichtingen zijn de inkomensverschillen doorgaans vrij groot. Oudstudenten van de avondopleiding Nederlands recht en basisartsen hebben gemiddeld de hoogste inkomens. 


\section{Aansluiting tussen gevolgde studie en functie}

\subsection{Voor de functie vereiste opleiding}

In dit hoofdstuk staat de aansluiting tussen de gevolgde studie en de huidige werkkring centraal. De aansluiting wordt vanuit twee invalshoeken benaderd. Eerst wordt in paragraaf 6.1 nagegaan in hoeverre de gevolgde studie vereist was voor de functie die men uitoefent. Het combineren van betaald werken met het volgen van een verdere opleiding komt vervolgens in paragraaf 6.2 aan bod. In paragraaf 6.3 worden de resultaten samengevat.

Aan de respondenten is gevraagd wat de minimale opleidingsvereisten voor de functie zijn. Wanneer de vereiste opleiding onder WO-niveau ligt, mag niet worden vergeten dat het hier om startfuncties gaat, waarbij mogelijk ook binnen de organisatie nog doorgroeimogelijkheden zijn naar functies op WO-niveau. De resultaten met betrekking tot het vereiste opleidingsniveau zijn weergegeven in tabel 6.1 .

Tabel 6.1

Procentueel aandeel van functies waarvoor een wetenschappelijke opleiding is vereist, circa één jaar na afstuderen, cohort '92 naar faculteit

\begin{tabular}{|c|c|c|c|c|c|c|}
\hline & \multirow[t]{2}{*}{ FdG } & \multirow[t]{2}{*}{ FdGW } & \multicolumn{2}{|c|}{ FdR } & \multirow[t]{2}{*}{ FdEW } & \multirow[t]{2}{*}{$\mathrm{RL}$} \\
\hline & & & dag & avond & & \\
\hline$\%$ WO-niveau & 98 & 60 & 62 & 75 & 66 & 67 \\
\hline Totaal n(=100\%) & 57 & 225 & 66 & 12 & 82 & 442 \\
\hline
\end{tabular}

Chi-square $=30.6 ;$ d.f. $=4 ; p<0.01$

Een derde van de betaald werkende oudstudenten werkt circa een jaar na het afstuderen in een functie die volgens de respondenten ook door lager opgeleiden zou kunnen worden uitgeoefend. De meesten oefenen echter functies uit waarvoor naar eigen zeggen een academische opleiding is vereist. Basisartsen zijn vrijwel uitsluitend in functies op academisch niveau werkzaam. Er is ook nagegaan of mannen en vrouwen verschillen ten aanzien van het voor de functie vereiste opleidingsniveau. Dit blijkt niet het geval te zijn $^{10}$.

Aan de respondenten is niet alleen gevraagd naar het niveau van de opleiding die voor hun functie werd vereist, maar ook naar de vereiste opleidingsrichting. In tabel 6.2 komt naar voren dat de meeste afgestudeerden functies hebben die qua vakgebied in het verlengde liggen van de studierichting die men aan de RL heeft gevolgd. Voor circa een derde van de functies werd de aan de RL gevolgde opleidingsrichting zelfs specifiek gevraagd (31\%). Basisartsen komen in meerderheid in dit soort functies terecht, dit wil zeggen in een geprofessionaliseerde vakdeelmarkt. In het geval van basisartsen verschaft uitsluitend een opleiding in de geneeskunde toegang tot de beroepen in deze vakdeelmarkt. Dit laat onverlet dat zo'n kwart van de basisartsen terecht komt buiten deze geprofessionaliseerde vakdeelmarkt van medische beroepen, waar sprake is van concurrentie door afgestudeerden van andere opleidingsrichtingen. Ruim een derde van de functies zou volgens de afgestudeerden ook kunnen worden vervuld door mensen met een verwante opleidingsrichting. Een minderheid van $17 \%$ oefent algemene functies uit, waarvoor het niet noodzakelijk is dat men in een bepaalde richting is afgestudeerd. Tenslotte

10. Chi-square $=3.7 ;$ d.f. $=1 ; p=0.05$. 
komt naar voren dat $15 \%$ uitwijkt naar functies waarvoor een andere opleidingsrichting werd gevraagd dan de richting die men aan de RL heeft gevolgd.

Tabel 6.2

Voor de functie vereiste opleidingsrichting, circa één jaar na afstuderen, cohort '92 naar faculteit (in \%)

\begin{tabular}{|c|c|c|c|c|c|c|}
\hline & \multirow[t]{2}{*}{ FdG } & \multirow[t]{2}{*}{ FdGW } & \multicolumn{2}{|c|}{ FdR } & \multirow[t]{2}{*}{ FdEW } & \multirow[t]{2}{*}{ RL } \\
\hline & & & dag & avond & & \\
\hline $\begin{array}{l}\text { Geen } \\
\text { Andere } \\
\text { Eigen of verwante } \\
\text { Eigen }\end{array}$ & $\begin{array}{r}14 \\
0 \\
10 \\
76\end{array}$ & $\begin{array}{l}20 \\
25 \\
42 \\
13\end{array}$ & $\begin{array}{l}12 \\
14 \\
42 \\
32\end{array}$ & $\begin{array}{r}8 \\
8 \\
38 \\
46\end{array}$ & $\begin{array}{r}14 \\
0 \\
43 \\
43\end{array}$ & $\begin{array}{l}17 \\
15 \\
38 \\
31\end{array}$ \\
\hline Totaal $n(=100 \%)$ & 58 & 221 & 66 & 13 & 84 & 442 \\
\hline
\end{tabular}

Chi-square $=220.3 ;$ d.f. $=16 ; p<0.01$

$\mathrm{Er}$ is ook nagegaan of mannen en vrouwen verschillen ten aanzien van de voor de functie vereiste opleidingsrichting. Gebleken is dat mannen (41\%) vaker dan vrouwen $(25 \%)$ terecht komen in functies waarvoor de aan de RL gevolgde opleidingsrichting specifiek is vereist.

\subsection{Combineren van werken en leren}

In deze paragraaf wordt ingegaan op het combineren van betaald werken met het volgen van een $2 \mathrm{e}$ fase opleiding of een post-doctorale (beroeps)opleiding. In tabel 6.3 wordt een beeld gegeven van de mate waarin afgestudeerden van cohort '92 betaald werken combineren met verder studeren. In de tabel komt naar voren dat één op iedere vijf afgestudeerden de functie combineert met verder leren, hetzij als $\mathrm{AIO}$ of OIO hetzij door het volgen van post-doctorale beroepsopleidingen (PDO). De laatstgenoemde opleidingen worden het vaakst gevolgd door economen.

Tabel 6.3

Combineren van betaald werken en leren binnen de functie, cohort '92 naar faculteit

\begin{tabular}{|c|c|c|c|c|c|c|}
\hline & \multirow[t]{2}{*}{ FdG } & \multirow[t]{2}{*}{ FdGW } & \multicolumn{2}{|c|}{$\mathrm{FdR}$} & \multirow[t]{2}{*}{ FdEW } & \multirow[t]{2}{*}{$\mathrm{RL}$} \\
\hline & & & dag & avond & & \\
\hline $\begin{array}{l}\text { als AIO/OIO } \\
\text { via PDO } \\
\text { nee }\end{array}$ & $\begin{array}{r}2 \\
18 \\
80\end{array}$ & $\begin{array}{r}7 \\
4 \\
89\end{array}$ & $\begin{array}{r}9 \\
20 \\
71\end{array}$ & $\begin{array}{r}0 \\
7 \\
93\end{array}$ & $\begin{array}{r}5 \\
34 \\
61\end{array}$ & $\begin{array}{r}6 \\
14 \\
80\end{array}$ \\
\hline Totaal $n(=100 \%)$ & 60 & 213 & 66 & 15 & 83 & 437 \\
\hline
\end{tabular}

Wat het combineren van betaald werken met het volgen van een post-doctorale beroepsopleiding betreft zijn er geen significante verschillen tussen mannen en vrouwen ${ }^{11}$.

Door de betaald werkende afgestudeerden van jaargang ' 92 worden de volgende post-doctorale beroepsopleidingen gevolgd.

11. Chi-square $=3.4 ;$ d.f. $=2 ; p=0.19$. 
- FdG: $12 \%$ opleiding voor medisch specialist; $2 \%$ opleiding voor sociaal geneeskundige; $2 \%$ opleiding voor huisarts; $3 \%$ overige opleidingsrichting.

- FdR: $11 \%$ advocatuur; $6 \%$ overige opleidingsrichtingen.

- FdEW: $28 \%$ accountancy; $2 \%$ controllers.

Eerder is naar voren gekomen dat het vinden van een betaalde baan voor basisartsen doorgaans geen probleem vormt. Het vinden van een medische opleidingsplaats is daarentegen wel degelijk problematisch. Circa een jaar na het afstuderen is slechts $18 \%$ van de betaald-werkende basisartsen van afstudeercohort ' 92 doorgestroomd naar een medische opleidingsplaats, terwijl $29 \%$ op zoek is naar een dergelijke plaats. In het vorige rapport is nagegaan welke kenmerken van basisartsen een rol spelen bij het al dan niet verwerven van een medische opleidingsplaats.

\subsection{Samenvatting}

Twee derde van de betaald werkenden heeft een functie waarvoor, naar eigen zeggen, een opleiding op academisch niveau is vereist (basisartsen zijn vrijwel uitsluitend in functies op academisch niveau werkzaam). De meesten (58\%) hebben functies die qua vakgebied in het verlengde liggen van de studierichting die men aan de RL heeft gevolgd. Voor bijna een derde van de functies werd de aan de RL gevolgde opleidingsrichting zelfs specifiek gevraagd (basisartsen komen meestal in dit soort functies terecht). Ruim een derde van de functies zou volgens de afgestudeerden ook kunnen worden vervuld door mensen met een verwante opleidingsrichting; $15 \%$ wijkt uit naar functies waarvoor een andere opleidingsrichting werd gevraagd dan de richting die men aan de RL heeft gevolgd. Circa een zesde (17\%) oefent algemene functies uit, waarvoor het niet noodzakelijk is dat men in een bepaalde richting is afgestudeerd.

Een vijfde van de betaald werkenden combineert verder leren en werken in de functie, hetzij als AIO of OIO $(6 \%)$ hetzij door het volgen van post-doctorale opleidingen (14\%). De laatstgenoemde opleidingen worden het vaakst gevolgd door economen. Er zijn meer basisartsen op zoek naar een medische opleidingsplaats $(29 \%)$ dan basisartsen die een medische opleidingsplaats hebben gevonden (18\%). 


\section{Trends in arbeidsmarktpositie}

\subsection{Beschrijving van de arbeidsmarktpositie}

Het begrip arbeidsmarktpositie kan worden herleid tot een drietal dimensies, namelijk de dimensie kans op werk, de dimensie kwaliteit van het werk en de dimensie uitwijkmogelijkheden op de arbeidsmarkt ${ }^{12}$. Deze dimensies kunnen worden benaderd met behulp van verschillende indicatoren:

- de dimensie kans op werk wordt geïndiceerd door het procentuele aandeel van afgestudeerden, behorend tot de beroepsbevolking, die op het moment van enquêtering werkloos zijn;

- voor de dimensie kwaliteit van het werk zijn achtereenvolgens als indicatoren gekozen: de zekerheid van de baan (geïndiceerd door het procentuele aandeel van in loondienst werkende afgestudeerden, die een vaste aanstelling hebben) en het niveau van de baan (geïndiceerd door het procentuele aandeel van banen waarvoor een academische opleiding is vereist en waarbij dus geen sprake is van onderbenutting van kwalificaties);

- de dimensie uitwijkmogelijkheden op de arbeidsmarkt is geoperationaliseerd aan de hand van het procentuele aandeel van academische banen waarvoor de aan de $\mathrm{RL}$ gevolgde opleidingsrichting niet specifiek is vereist.

De dimensies kans op werk en kwaliteit van het werk kunnen worden beschouwd als indicatoren van de actuele arbeidsmarktpositie, die in beginsel van jaar tot jaar (sterk) kunnen variëren. Deze actuele indicatoren geven derhalve een beeld van de huidige aansluitingsproblematiek. Daarbij kan een onderscheid worden gemaakt tussen kwantitatieve aansluitingsproblemen of absorptieproblemen enerzijds (kans op werk) en kwalitatieve aansluitingsproblemen of benuttingsproblemen anderzijds (niveau van het werk in relatie tot de opleiding). De dimensie uitwijkmogelijkheden op de arbeidsmarkt karakteriseert de risico's die afgestudeerden van een bepaalde opleiding min of meer structureel ondervinden op de arbeidsmarkt. Zo hebben afgestudeerden van een opleiding met relatief veel uitwijkmogelijkheden een grote kans om ook buiten hun 'eigen' beroependomein een baan te vinden. Afgestudeerden van een opleiding met relatief weinig uitwijkmogelijkheden zijn daarentegen sterk afhankelijk van de werkgelegenheidsontwikkeling binnen het arbeidsmarktsegment waarvoor wordt opgeleid.

Op basis van de bovengenoemde indicatoren kan de arbeidsmarktpositie van een opleiding variëren tussen twee uitersten. Aan de ene kant een sterke arbeidsmarktpositie. Hiervan is sprake wanneer de afgestudeerden een grote kans op werk hebben, een hoge mate van baanzekerheid kennen, weinig risico lopen onderbenut te worden en weinig uitwijken buiten het eigen beroependomein. Daarentegen is de arbeidsmarktpositie zwak wanneer de afgestudeerden, ondanks het feit dat zij maximaal uitwijken buiten het eigen beroependomein, een geringe kans op werk hebben, weinig baanzekerheid kennen en veel risico lopen onderbenut te worden. Doorgaans zal de arbeidsmarktpositie tussen deze twee extremen in liggen. Zo kunnen afgestudeerden in (conjunctureel) moeilijke tijden hun kans op werk vergroten door kwalitatief mindere banen te accepteren en vaker uit te wijken naar andere arbeidsmarktsegmenten (de uitwijkmogelijkheden van hun opleiding bepalen hierbij de speelruimte die zij hebben om te kunnen uitwijken). Een opleiding die op de ene dimensie een goede positie inneemt, heeft derhalve niet vanzelfsprekend op de andere dimensie ook een goede positie.

In dit hoofdstuk wordt ingegaan op de ontwikkelingen die zich in de arbeidsmarktpositie van de afstudeerjaargangen ' $88 \mathrm{t} / \mathrm{m}$ '92 hebben afgetekend. Deze ontwikkelingen worden aan de hand van de

12. De Grip, Van der Velden en Wieling (1993), Van der Velden en Wieling (1994). 
bovengeschetste drie dimensies achtereenvolgens in kaart gebracht. Daarnaast wordt nagegaan in welke mate de vijf achtereenvolgende cohorten zich oriënteren op de landelijke arbeidsmarkt. Als indicator voor de werkregio is gekeken naar het procentuele aandeel van betaald werkende afgestudeerden die buiten de regio Zuid-Limburg zijn gaan werken.

\section{Kans op werk}

Grafiek 7.1

Werkloosheid* circa een jaar na afstuderen, cohort '89-'92 naar faculteit (in \%)

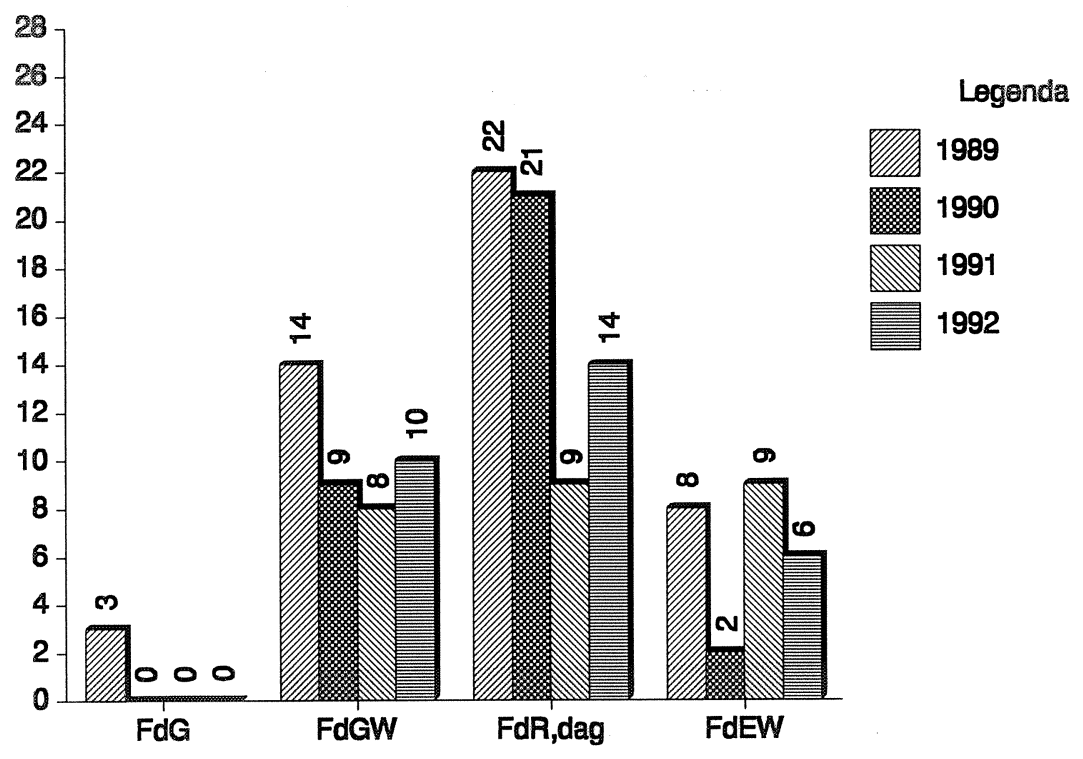

Toelichting:

- Procentueel aandeel van afgestudeerden, behorend tot de beroepsbevolking, die werkloos zijn.

- Vanwege een voor het eerst bij cohort ' 89 doorgevoerde wijziging in de vraagstelling zijn vergelijkbare cijfers voor afstudeercohort ' 88 niet beschikbaar.

Grafiek 7.1 schetst de omvang van de werkloosheid, gemeten circa een jaar na het afstuderen, onder de afstudeercohorten ' $89 \mathrm{t} / \mathrm{m}$ ' 92 . Hierbij is het aandeel van werklozen uitgedrukt als percentage van de afgestudeerden die tot de beroepsbevolking behoren. Voor de in dit rapport gehanteerde definitie van de begrippen werkloos en beroepsbevolking wordt verwezen naar paragraaf 3.3. De grafiek laat duidelijk zien dat van de opeenvolgende cohorten afgestudeerde basisartsen vrijwel niemand werkloos is geworden. Zowel bij gezondheidswetenschappers als bij juristen die de dagopleiding hebben gevolgd, kan worden geconstateerd dat de werkloosheid na een aanvankelijke daling bij de laatste afstudeerjaargang toeneemt. De werkloosheid onder de opeenvolgende afstudeerjaargangen economen geeft een schommelend verloop te zien.

De werkloosheid onder de tweede lichting juristen die de avondopleiding hebben gevolgd ( $0 \%$ werkloos), verschilt niet significant van de werkloosheid onder de eerste lichting die in 1991 is afgestudeerd (3\% werkloos). 


\section{Kwaliteit van het werk}

De kwaliteit van het werk wordt achtereenvolgens geïndiceerd door het procentuele aandeel van in loondienst werkende afgestudeerden die een vaste baan hebben (baanzekerheid) en het procentuele aandeel van banen waarvoor een academische opleiding is vereist (niveau van het werk).

\section{Baanzekerheid}

Het vaste of tijdelijke karakter van de arbeidsovereenkomst in loondienst geeft een indicatie van de zekerheid van iemand's baan. Grafiek 7.2 schetst de ontwikkeling van de mate waarin de opeenvolgende afstudeerjaargangen er in zijn geslaagd om vaste aanstellingen te verwerven. In de grafiek komt naar voren dat aan de gestaag toenemende baanzekerheid onder de opeenvolgende cohorten basisartsen bij de laatste afstudeerjaargang een einde lijkt te zijn gekomen. De opeenvolgende cohorten gezondheidswetenschappers daarentegen blijven er steeds vaker in slagen om vaste aanstellingen te verwerven. Bij economen en juristen die de dagopleiding hebben gevolgd, geeft de ontwikkeling van de baanzekerheid een identiek verloop te zien: aanvankelijk een daling, afgewisseld door een piek bij cohort '91, en gevolgd door opnieuw een daling bij de laatste afstudeerlichting.

De tweede lichting juristen die de avondopleiding hebben gevolgd, is nagenoeg even vaak in vaste aanstellingen werkzaam ( $86 \%)$ als de eerste lichting ( $84 \%$ vaste aanstellingen).

\section{Grafiek 7.2}

Procentueel aandeel van vaste aanstellingen, cohort ' $88-' 92$ naar faculteit

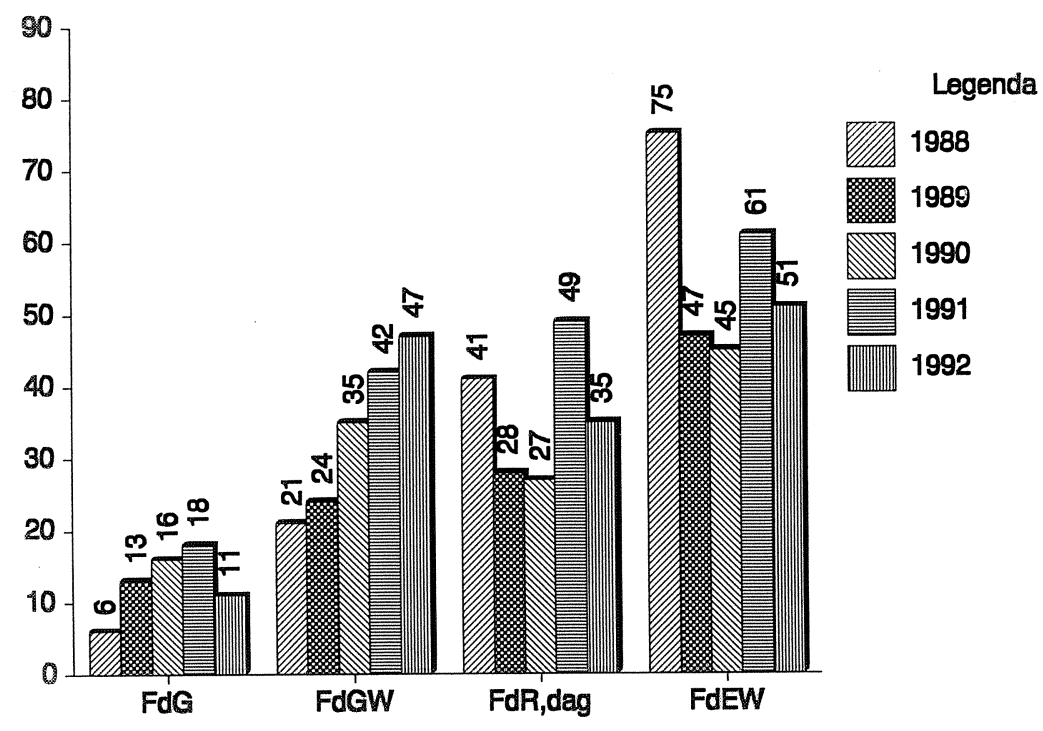

Toelichting:

- In deze grafiek zijn uitsluitend banen in loondienst begrepen van afgestudeerden die tenminste 12 uur per week betaalde arbeid verrichten. 


\section{Niveau van het werk}

Wat het voor de functie vereiste opleidingsniveau betreft, laat grafiek 7.3 zien dat de opeenvolgende lichtingen basisartsen vrijwel uitsluitend functies op academisch niveau blijven uitoefenen. De laatste afstudeerjaargang gezondheidswetenschappers blijkt minder vaak dan eerdere lichtingen in functies op academisch niveau terecht te komen. De opeenvolgende afstudeerjaargangen juristen die de dagopleiding hebben gevolgd, gaan steeds vaker uitwijken naar functies onder hun niveau. Dit is ook het geval bij de drie laatste jaargangen economen.

De tweede afstudeerlichting van de avondopleiding Nederlands recht oefent vaker functies op academisch niveau uit $(75 \%)$ dan hun voorgangers $(54 \%)$.

Grafiek 7.3

Procentueel aandeel van functies waarvoor een academische opleiding is vereist, cohort ' $89-' 92$ naar faculteit

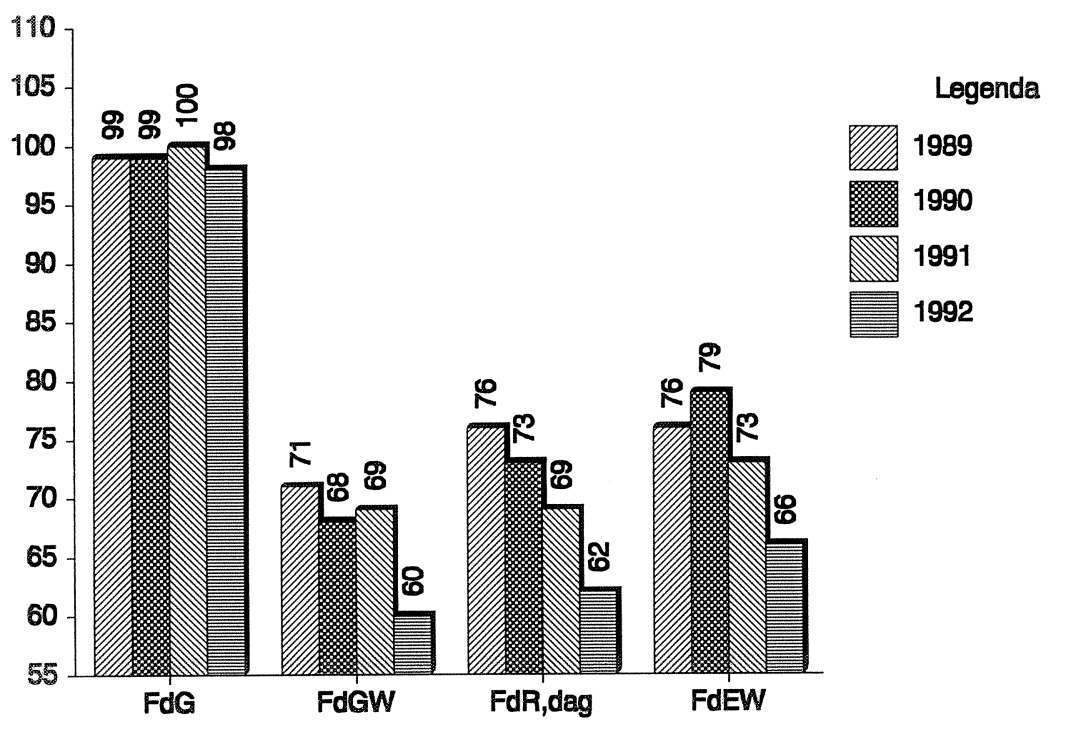

Toelichting:

- In deze grafiek zijn uitsluitend banen begrepen van afgestudeerden die tenminste 12 uur per week betaalde arbeid verrichten.

- Met afstudeerjaargang ' 88 kan geen vergelijking worden gemaakt, omdat de vraag naar de vvor de functie vereiste opleiding voor het eerst is voorgelegd aan cohort ' 89 .

\section{Uitwijkmogelijkheden}

Grafiek 7.4 geeft een beeld van de mate waarin afgestudeerden, die werkzaam zijn in academische functies, uitwijken naar banen waarvoor de aan de RL gevolgde 'eigen' studierichting niet specifiek is vereist. De grafiek laat zien dat zowel basisartsen als gezondheidswetenschappers in toenemende mate uitwijken naar academische functies die ook zouden kunnen worden vervuld door in andere disciplines opgeleide academici. Ook bij juristen die de dagopleiding hebben gevolgd, kan worden geconstateerd dat de twee laatste afstudeerjaargangen beduidend vaker dan hun voorgangers zijn uitgeweken naar banen buiten hun opleidingsdomein. Wat het uitwijken naar qua vereiste opleidingsrichting 'andere' banen 
betreft, lijkt bij economen sprake te zijn geweest van een incidentele piek onder afstudeerjaargang ' 91 .

Vergeleken met hun voorgangers wijken de in 1992 afgestudeerde oud-avondstudenten Nederlands recht vaker uit naar academische functies waarvoor het niet expliciet nodig is dat men rechten heeft gestudeerd. Van de eerste lichting oud-avondstudenten Nederlands recht, werkzaam in academische banen, is $47 \%$ uitgeweken naar functies die ook zouden kunnen worden vervuld door niet-juristen. Bij cohort ' 92 is dit opgelopen naar $56 \%$.

Grafiek 7.4

Procentueel aandeel van functies waarvoor de 'eigen' studierichting niet specifiek is vereist, cohort ' 89 -'92 naar faculteit

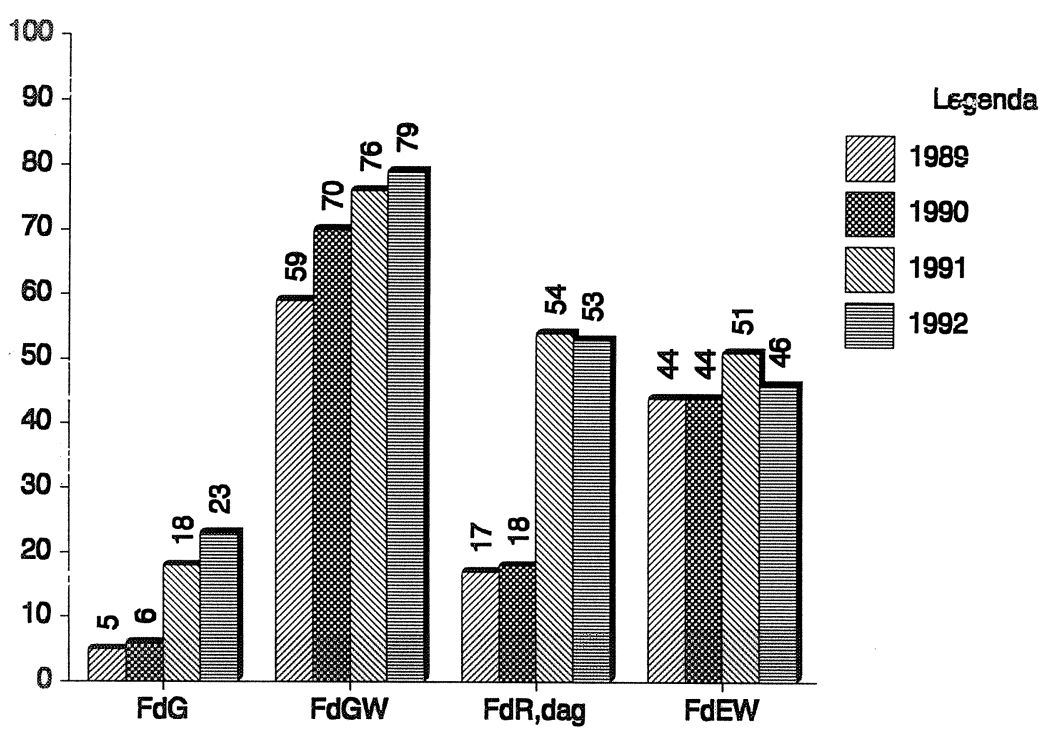

Toelichting:

- In deze grafiiek zijn uitsiuiiend banen op academisch niveau begrepen van afgestudeerden die tenminste 12 uur per week betaalde arbeid verrichten.

- Met afstudeerjaargang '88 kan geen vergelijking worden gemaakt, omdat de vraag naar de vvor de functie vereiste opleiding voor het eerst is voorgelegd aan cohort ' 89.

\subsection{Werkregio}

Grafiek 7.5 laat zien dat de opeenvolgende cohorten basisartsen in toenemende mate buiten de regio zijn gaan werken. Zowel bij juristen die de dagopleiding hebben gevolgd als bij economen kan worden geconstateerd dat de laatste jaargang afgestudeerden vaker dan vroegere cohorten uitwijkt naar gebieden buiten de regio Zuid-Limburg. Bij gezondheidswetenschappers lijkt sprake te zijn van incidentele pieken en dalen in het aandeel van oud-studenten die buiten de regio gaan werken.

De tweede lichting oud-avondstudenten Nederlands recht is vaker buiten Zuid-Limburg gaan werken (39\%) dan hun voorgangers die in 1991 zijn afgestudeerd. Van deze eerste lichting is slechts $11 \%$ in gebieden buiten de regio gaan werken. 
Grafiek 7.5

Procentueel aandeel van ałgestudeerden die buiten Zuid-Limburg* werken, cohort ' 88 -' 92 naar faculteit

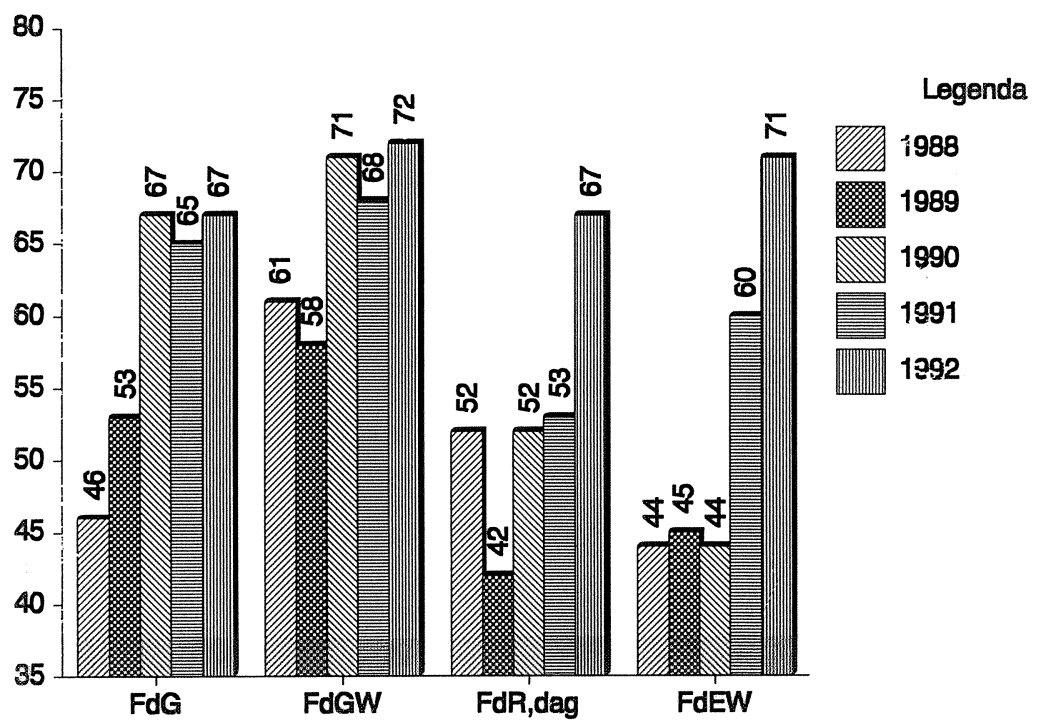

Toelichting:

- * De postcodegebieden $61 \mathrm{t} / \mathrm{m} 64$.

- In deze grafiek zijn uitsluitend banen begrepen van afgestudeerden die tenminste 12 uur per week betaalde arbeid verrichten.

\subsection{Schatting van de arbeidsmarktpositie}

In deze paragraaf wordt de arbeidsmarktpositie die de afstudeercohorten 1989 tot en met 1992 circa één jaar na het afstuderen innemen aan de hand van een viertal indicatoren geanalyseerd. Met behulp van logistische regressievergelijkingen is achtereenvolgens de kans geschat dat:

- afgestudeerden, behorend tot de beroepsbevolking, op het moment van enquêtering werkzaam zijn;

- in loondienst werkende afgestudeerden op het moment van enquêtering een vaste aanstelling hebben;

- voor de baan die men op het moment van enquetering heeft een academische opleiding is vereist;

- voor de academische baan die men op het moment van enquêtering heeft de 'eigen' opleidingsrichting is vereist.

De resultaten van deze schattingen worden achtereenvolgens in tabel 7.1, 7.2, 7.3 en 7.4 weergegeven. De eerste kolom in deze tabellen geeft steeds de verklarende variabelen weer, de tweede kolom de geschatte regressiecoëfficiënten en uit de in de derde kolom vermelde standaardfout kan worden afgeleid of het gevonden effect significant is.

De eerste te verklaren variabele kans op werk heeft de waarde 1 indien de respondent op het moment van enquêtering tot de beroepsbevolking behoort en werkzaam is, en 0 indien de respondent op het moment van enquêtering tot de beroepsbevolking behoort en werkloos is. De tweede te verklaren variabele kans op vast werk heeft de waarde 1 indien de in loondienst werkende afgestudeerde een vaste aanstelling heeft, en 0 indien de in loondienst werkende afgestudeerde een tijdelijke aanstelling heeft. De derde te verklaren variabele niveau-aansluitend werk heeft de waarde 1 indien voor de functie volgens opgave van de respondenten een wetenschappelijke opleiding is vereist, en 0 indien voor de 
functie volgens opgave van de respondenten een wetenschappelijke opleiding niet is vereist. De vierde te verklaren variabele richting-aansluitend academisch werk heeft de waarde 1 indien voor de academische functie volgens opgave van de respondenten de aan de RL gevolgde opleidingsrichting specifiek is vereist, en 0 indien voor de academische functie volgens opgave van de respondenten de aan de RL gevolgde opleidingsrichting niet specifiek is vereist. Voor de preciese omschrijving van de dummy-codes wordt verwezen naar bijlage 2 .

In de schattingen is een aantal verklarende variabelen opgenomen, waarvan wordt aangenomen dat zij zowel de kans op werk en de zekerheid van het werk als de aansluiting (qua niveau en richting) van het werk op de opleiding kunnen beïnvloeden. Als verklarende variabelen zijn in iedere schatting steeds twee persoonskenmerken, vier kwalificatiekenmerken van de respondenten en twee loopbaankenmerken opgenomen. Bij de twee persoonskenmerken gaat het om de leeftijd in het jaar van afstuderen en het geslacht. De kwalificaties waarmee men de arbeidsmarkt betreedt, hebben betrekking op de genoten vooropleiding en de aan de RL gevolgde opleidingsrichting, alsmede op de betaalde werkervaring en bestuurlijke ervaring die men voor of tijdens de studie aan de RL heeft opgedaan. De twee loopbaankenmerken betreffen het afstudeercohort waartoe men behoort en het aantal maanden dat men op het moment van enquêteren reeds is afgestudeerd.

Voor deze verklarende variabelen zijn dummies geconstrueerd, behoudens voor de leeftijd in jaren (leeftijd) en het aantal maanden dat men reeds is afgestudeerd (maanden na afstuderen). Met betrekking tot de variabele leeftijd dient te worden vermeld dat drie procent van de respondenten ouder dan 40 jaar is. Om te voorkomen dat de hoge leeftijden van deze kleine groep een te zware wissel zouden trekken op de analyseresultaten, is de leeftijd van deze veertigplussers in de analyses op 41 jaar gesteld. De dummy-variabelen hebben achtereenvolgens betrekking op mannelijk geslacht, het beschikken over een diploma van een opleiding in het hoger onderwijs voordat men aan de RL kwam studeren (HO-diploma), het beschikken over betaalde werkervaring, opgedaan vóór of tijdens de studie aan de RL (werkervaring voor afstuderen), het beschikken over bestuurlijke ervaring, opgedaan vóór of tijdens de studie aan de $\mathrm{RL}$ (bestuurlijke ervaring), het jaar waarin men aan de RL is afgestudeerd (cohort '89, cohort '90, cohort '91 en cohort ' $92^{13}$ ) en de aan de RL gevolgde opleidingsrichting: geneeskunde, $B B$ (beleid en beheer van gezondheidszorgvoorzieningen), BW (bewegingswetenschappen), BGK (biologische gezondheidkunde), GGK (geestelijke gezondheidkunde), GVO (gezondheidsvoorlichting), VW (verplegingswetenschap), dagopleiding Ned. recht, avondopleiding Ned. recht en economie ${ }^{14}$.

In iedere schatting fungeerde geneeskunde als referentie voor de gevolgde studierichting en cohort ' 89 als referentie voor het jaar waarin men aan de RL is afgestudeerd. Voor de preciese omschrijving van de dummy-codes wordt verwezen naar bijlage 2 .

Er wordt verondersteld dat de kans op werk, de zekerheid van het werk en de aansluiting van het werk op de opleiding per opleidingsrichting en per afstudeerjaar verschilt. Verder wordt verwacht dat discriminatie op basis van geslacht ertoe kan leiden dat vrouwen een kleinere kans dan mannen hebben op betaald werk, op vast werk en vaker dan mannen zijn gedwongen om uit te wijken naar functies beneden

13. Afstudeerjaargang ' 88 is niet meegenomen in de drie schattingen, aangezien voor dit cohort vergelijkbare gegevens over de kans op werk ontbreken en de vraag naar de voor de functie vereiste opleiding voor het eerst is voorgelegd aan afstudeerjaargang ' 89 .

14. Aangezien zich onder de respondenten slechts 20 oud-studenten TGW (theorie der gezondheidswetenschappen) bevinden, heeft het opnemen van een dummy voor deze afstudeervariant binnen gezondheidswetenschappen weinig zin. Vandaar dat de 20 oud-studenten TGW niet in deze analyses zijn opgenomen. 
het behaalde opleidingsniveau en naar academische functies die niet aansluiten bij de gevolgde opleidingsrichting. Vanwege een aantal redenen mag worden verwacht dat jongeren een grotere kans op werk, vast werk en richting-aansluitend academisch werk hebben dan ouderen. Jongeren zijn doorgaans flexibeler dan ouderen, en kunnen zich daardoor wellicht makkelijker aanpassen aan de specifieke cultuur van de werkorganisatie. Bovendien zullen jongeren wellicht eerder bereid zijn om aanvullende (bedrijfsspecifieke) opleidingen te volgen, aangezien hun investering in aanvullend onderwijs gedurende een groter aantal arbeidsjaren tot een hoger inkomen zal leiden. Vanuit de werkgever gezien kunnen de in bedrijfsopleidingen geïnvesteerde tijd en kosten, middels de verwachte hogere arbeidsproductiviteit, bij jongeren over een groter aantal arbeidsjaren worden terugverdiend. Daarbij komt dat voor jongeren, vanwege het groter aantal arbeidsjaren dat zij nog voor zich hebben, een flexibeler loopbaanplanning mogelijk is: zij zijn makkelijker in lagere startfuncties inzetbaar, om van daaruit, mede door het volgen van bedrijfsspecifieke opleidingen, door te stromen naar hogere functies in de organisatie. Gezien dit laatste wordt verwacht dat jongeren een grotere kans dan ouderen hebben om in functies onder hun opleidingsniveau terecht te komen. Extra kwalificaties in de vorm van het reeds beschikken over een HOdiploma vóórdat men aan de RL gaat studeren en betaalde werkervaring of bestuurlijke ervaring, opgedaan vóór of tijdens de studie aan de RL, maken iemand voor een werkgever aantrekkelijker waardoor de kans toeneemt om vast werk op academisch niveau te vinden dat aansluit op de opleidingsrichting die men heeft gevolgd. Tenslotte wordt verondersteld dat de kans op werk, de kans op een vaste aanstelling en de kans dat de functie qua niveau en richting aansluit bij de genoten opleiding toeneemt met het aantal maanden dat men inmiddels is afgestudeerd. Immers, naarmate men langer op de arbeidsmarkt verblijft, heeft men ook meer tijd gehad om een vaste baan te verwerven die aansluit op het niveau en de richting van de gevolgde opleiding.

Op basis van de hiervoor genoemde veronderstellingen en de wijze waarop de variabelen zijn geoperationaliseerd, worden positieve effecten verwacht voor mannelijk geslacht, het aantal maanden dat men reeds is afgestudeerd, alsmede voor HO-diploma en werk- en bestuurlijke ervaring, opgedaan vóór het afstuderen. Voor leeftijd worden negatieve parametertekens verwacht bij de kans op werk, de kans op vast werk en de kans op richting-aansluitend academisch werk, en een positief parameterteken bij de kans op niveau-aansluitend werk. Deze effecten kunnen evenwel per opleidingsrichting verschillen.

\section{Kans op werk}

Als eerste is de kans geschat dat afgestudeerden die tot de beroepsbevolking behoren op het moment van de enquête werkzaam zijn, dit wil zeggen gedurende tenminste 12 uur per week betaald werk verrichten of militaire danwel vervangende dienstplicht vervullen. In de analyse, waarvan de resultaten in tabel 7.1 staan vermeld, komt naar voren dat de kans op werk tegen de verwachting in niet significant wordt beïnvloed door het geslacht, de bestuurlijke ervaring die men voor of tijdens de studie aan de RL eventueel heeft opgedaan en het jaar waarin men is afgestudeerd. Het effect van de cohortdummies voor afstudeerjaar ' 91 en ' 92 is overigens bijna significant. In de analyse komt naar voren dat degenen die na 1990 zijn afstudeerd vaker (hoewel net niet significant vaker) werk hebben gevonden dan afstudeercohort ' 89 , dat in de analyse als referentiecategorie voor het afstudeerjaar heeft gefungeerd.

De kans om werk te verwerven is wel afhankelijk van de vooropleiding, de betaalde werkervaring waarover men op het moment van afstuderen eventueel reeds beschikt, de gevolgde opleidingsrichting, de leeftijd en het aantal maanden dat men reeds is afgestudeerd. Op deze beïnvloedende factoren zal hieronder nader worden ingegaan.

Zoals verwacht, maken extra kwalificaties in de vorm van het reeds beschikken over een HO-diploma 
vóórdat men aan de RL gaat studeren iemand voor een werkgever aantrekkelijker, waardoor de kans toeneemt om na het afstuderen betaald werk te vinden. Eveneens conform de verwachting heeft de betaalde werkervaring die men vóór of tijdens de studie heeft opgedaan een positief effect op de intrede in het arbeidsproces: óf men is na het afstuderen blijven werken in de baan die men al tijdens de studie had, óf men heeft meer kans om een betaalde baan te krijgen. Eveneens volgens de verwachting komt naar voren dat de kans op werk toeneemt naarmate men meer tijd heeft gehad om werk te zoeken. Verder is gebleken dat jongere afgestudeerden meer kans op een baan hebben dan ouderen.

In paragraaf 3.3 is naar voren gekomen dat van de oud-avondstudenten Nederlands recht en de basisartsen die zich op de arbeidsmarkt aanbieden niemand werkloos is. Het is dan ook niet verwonderlijk dat in de uitgevoerde analyse het percentage afgestudeerden die op het moment van enquêteren een baan hebben bij de avondopleiding Nederlands recht niet significant afwijkt van het percentage bij basisartsen (de referentiegroep). Bij de andere opleidingen is de arbeidsmarktintrede van de afgestudeerden significant moeizamer verlopen dan bij de referentiecategorie, geneeskunde.

Tabel 7.1

Logistische regressie van de kans op werk, cohort ' 89 - '92

\begin{tabular}{|c|c|c|}
\hline & $\begin{array}{l}\text { regressie- } \\
\text { coëfficiënt }\end{array}$ & $\begin{array}{l}\text { standaard- } \\
\text { fout }\end{array}$ \\
\hline $\begin{array}{l}\text { HO-vooropleiding } \\
\text { Werkervaring voor afstuderen } \\
\text { Bestuurlijke ervaring }\end{array}$ & $\begin{array}{l}.91^{\star *} \\
.68^{* *} \\
.16\end{array}$ & $\begin{array}{l}.35 \\
.21 \\
.21\end{array}$ \\
\hline $\begin{array}{l}\text { BB } \\
\text { BW } \\
\text { BGK } \\
\text { GGK } \\
\text { GVO } \\
\text { WW } \\
\text { Dagopleiding Ned. recht } \\
\text { Avondopleiding Ned. recht } \\
\text { Economie }\end{array}$ & $\begin{array}{l}-2.14^{\star \star} \\
-3.51^{\star \star} \\
-2.41^{\star \star} \\
-2.99^{\star \star} \\
-2.70^{\star \star} \\
-2.39^{\star \star} \\
-3.05^{\star \star} \\
-1.07 \\
-2.31^{\star *}\end{array}$ & $\begin{array}{r}.67 \\
.67 \\
.73 \\
.67 \\
.69 \\
.70 \\
.60 \\
1.21 \\
.65\end{array}$ \\
\hline $\begin{array}{l}\text { Mannelijk geslacht } \\
\text { Leeftijd }\end{array}$ & $\begin{array}{l}.12 \\
-.07^{\star}\end{array}$ & $\begin{array}{l}.21 \\
.03\end{array}$ \\
\hline $\begin{array}{l}\text { Cohort } 90 \\
\text { Cohort } 91 \\
\text { Cohort } 92 \\
\text { Maanden na afstuderen }\end{array}$ & $\begin{array}{l}.38 \\
.50 \\
.50 \\
.10^{\star \star}\end{array}$ & $\begin{array}{l}.28 \\
.28 \\
.27 \\
.03\end{array}$ \\
\hline Constante & $4.17^{\star \star \star}$ & 1.04 \\
\hline
\end{tabular}

* significant op $5 \%$ niveau

** significant op $1 \%$ niveau

Model Chi-square $=110.1 ;$ d.f. $=18 ; p<0.01$

Percentage correct $=91$

$n=1521$

Kans op vast werk

$\mathrm{Na}$ de analyse van de kans op werk, is de kans geschat dat de in loondienst werkende afgestudeerden een vaste aanstelling hebben. De resultaten van deze schatting staan vermeld in tabel 7.2. Tegen de verwachting in blijkt de kans op een vaste aanstelling niet significant te worden beïnvloed door het geslacht en de extra kwalificaties waarover men beschikt (een HO-diploma vóórdat men aan de RL gaat studeren en de betaalde werkervaring en bestuurlijke ervaring die men voor of tijdens de studie aan de 
RL heeft opgedaan). Evenmin is de tijdsduur die men reeds is afgestudeerd van invloed op de kans dat men een vaste baan heeft, tenminste gemeten ongeveer een jaar na het afstuderen.

De kans op een vaste baan blijkt wel afhankelijk te zijn van de opleidingsrichting die men gevolgd heeft, de leeftijd en het jaar waarin men is afgestudeerd. Vergeleken met basisartsen hebben alle afgestudeerden, behoudens oudstudenten BGK en GGK, een grotere kans om een vaste aanstelling te krijgen. Hierbij dient te worden bedacht dat van alle afgestudeerden de basisartsen (referentiegroep in de schatting) het vaakst in tijdelijke dienst werkzaam zijn (zie tabel 5.3). Verder komt naar voren dat oudere afgestudeerden vaker een vaste aanstelling hebben dan jongere afgestudeerden.

Tot slot kan worden geconstateerd dat degenen die in 1991 en 1992 zijn afgestudeerd significant vaker vast werk hebben gekregen dan afstudeercohort ' 89 , dat in de analyse als referentiecategorie voor het afstudeerjaar heeft gefungeerd. De bevinding dat degenen die na 1990 zijn afgestudeerd vaker vast werk hebben gekregen dan afstudeerjaargang '89 lijkt er op het eerste oog op te duiden dat de arbeidsmarktsituatie voor intrede academici de laatste jaren is verbeterd. Wanneer echter ook wordt gekeken naar de kwaliteit van het werk, dan zou het plaatje er wel eens heel anders kunnen komen uit te zien. Vandaar dat ook de kwaliteit van het werk, geïndiceerd door de aansluiting (qua niveau en richting) van het werk op de opleiding nader is geanalyseerd.

Tabel 7.2

Logistische regressie van de kans op vast werk, cohort ' 89 - '92

\begin{tabular}{lcc}
\hline & $\begin{array}{c}\text { regressie- } \\
\text { coëfficiënt }\end{array}$ & $\begin{array}{c}\text { standaard- } \\
\text { fout }\end{array}$ \\
\hline HO-vooropleiding & .27 & .19 \\
Werkervaring voor afstuderen & -.00 & .15 \\
Bestuurlijke ervaring & -.13 & .14 \\
BB & $1.55^{\star *}$ & .25 \\
BW & $1.18^{\star *}$ & .35 \\
BGK & .37 & .40 \\
GGK & .60 & .37 \\
GVO & $.73^{*}$ & .34 \\
WW & $1.53^{* *}$ & .28 \\
Dagopleiding Ned. recht & $1.29^{* *}$ & .23 \\
Avondopleiding Ned. recht & $2.83^{\star *}$ & .58 \\
Economie & $1.96^{\star *}$ & .25 \\
& .06 & .15 \\
Mannelijk geslacht & $.07^{\star *}$ & .02 \\
Leeftijd & .25 & .22 \\
Cohort 90 & $.62^{* *}$ & .21 \\
Cohort 91 & $.52^{*}$ & .21 \\
Cohort 92 & -.00 & .02 \\
Maanden na afstuderen & $-4.02^{*}$ & .65 \\
Constante & & \\
\hline
\end{tabular}

$\begin{array}{ll}\star & \text { significant op } 5 \% \text { niveau } \\ \star * & \text { significant op } 1 \% \text { niveau }\end{array}$

Model Chi-square $=208.7 ;$ d.f. $=18 ; p<0.01$

Percentage correct $=69$

$n=1238$

Kans op niveau-aansluitend werk

De schattingsresultaten van de kans dat men op of onder WO-niveau werkzaam is, worden in tabel 7.3 weergegeven. Uit de resultaten blijkt dat de kans om een functie op academisch niveau te verwerven niet 
significant wordt beïnvloed door het geslacht, de leeftijd, het al dan niet beschikken over een HO-diploma vóórdat men aan de RL gaat studeren, de eventuele bestuurlijke ervaring die men voor of tijdens de studie aan de RL heeft opgedaan en het aantal maanden dat men reeds is afgestudeerd. De kans op niveau-aansluitend werk hangt wel samen met de eventuele betaalde werkervaring, opgedaan voor of tijdens de studie aan de RL, de opleidingsrichting die men aan de RL heeft gevolgd en het jaar waarin men is afgestudeerd. Afgestudeerden die reeds voor of tijdens de studie betaalde werkervaring hebben opgedaan, blijken een grotere kans te hebben om na het afstuderen werk te krijgen dat qua niveau aansluit bij de gevolgde opleiding.

Uit de negatieve parametertekens van alle in tabel 7.3 vermelde opleidingsrichtingen blijkt dat de desbetreffende afgestudeerden een kleinere kans dan basisartsen (de referentiegroep) hebben om in academische functies terecht te komen. Dit is niet verwonderlijk aangezien basisartsen als enigen vrijwel uitsluitend in functies op academisch niveau werkzaam zijn (zie tabel 6.1).

De negatieve parametertekens en de groter wordende coëfficiënten bij de afstudeercohorten wijzen er op dat afgestudeerden in toenmende mate uitwijken naar banen onder hun opleidingsniveau. Het laatste afstudeercohort is zelfs significant vaker dan jaargang ' 89 (de referentiegroep) in dit soort functies terecht gekomen. Mogelijk accepteren afgestudeerden in toenemende mate functies beneden hun opleidingsniveau in ruil voor een grotere baanzekerheid. De bevinding in tabel 7.2 dat degenen die na 1990 zijn afstudeerd significant vaker vast werk hebben gekregen dan afstudeercohort ' 89 wijst in deze richting.

Tabel 7.3

Logistische regressie van de kans op niveau-aansluitend werk, cohort '89 - '92

\begin{tabular}{lll}
\hline & $\begin{array}{c}\text { regressie- } \\
\text { coëfficiënt }\end{array}$ & $\begin{array}{c}\text { standaard- } \\
\text { fout }\end{array}$ \\
\hline HO-vooropleiding & -.09 & .19 \\
Werkervaring voor afstuderen & $.52^{\star *}$ & .16 \\
Bestuurlijke ervaring & .19 & .15 \\
BB & $-3.83^{\star *}$ & .61 \\
BW & $-4.32^{\star *}$ & .65 \\
BGK & $-3.16^{\star *}$ & .68 \\
GGK & $-3.53^{\star *}$ & .65 \\
GVO & $-4.64^{* *}$ & .64 \\
WW & $-4.21^{\star *}$ & .62 \\
Dagopleiding Ned. recht & $-3.77^{\star *}$ & .60 \\
Avondopleiding Ned. recht & $-4.15^{\star *}$ & .71 \\
Economie & $-3.69^{* *}$ & .61 \\
Mannelijk geslacht & -.00 & .16 \\
Leeftijd & -.02 & .02 \\
Cohort 90 & -.09 & .24 \\
Cohort 91 & -.13 & .22 \\
Cohort 92 & $-.44^{*}$ & .22 \\
Maanden na afstuderen & -.01 & .02 \\
Constante & $5.09^{* *}$ & .86 \\
\hline
\end{tabular}

* $\quad$ significant op $5 \%$ niveau

significant op $1 \%$ niveau

Model Chi-square $=217.5 ;$ d.f. $=18 ; p<0.01$

Percentage correct $=74$

$n=1287$ 
Bij de aansluiting van het werk op de opleiding is in de eerste plaats gekeken naar het niveau van de opleiding die voor de functie is vereist. Voor functies op academisch niveau is bovendien gekeken naar de richting van de opleiding die vereist is. Tabel 7.4 toont de schattingsresultaten van de kans dat voor de academische baan die men op het moment van enquêtering heeft de 'eigen' opleidingsrichting is vereist. Het blijkt dat deze kans niet afhangt van iemand's geslacht en leeftijd, noch van de extra kwalificaties waarover men eventueel beschikt (in de vorm van een HO-diploma vóórdat men aan de RL gaat studeren of in de vorm van de betaalde werkervaring en bestuurlijke ervaring die men voor of tijdens de studie aan de RL heeft opgedaan). Evenmin speelt de tijdsduur die men reeds is afgestudeerd een rol van betekenis, tenminste gemeten ongeveer een jaar na het afstuderen.

Uit de negatieve parametertekens van alle in tabel 7.4 vermelde opleidingsrichtingen blijkt dat de desbetreffende afgestudeerden een kleinere kans dan basisartsen (de referentiegroep) hebben om in academische functies terecht te komen, waarvoor de 'eigen' opleidingsrichting specifiek is vereist. Hierbij dient te worden bedacht dat basisartsen als enigen in meerderheid in een geprofessionaliseerde vakdeelmarkt werkzaam zijn, waartoe alleen de 'eigen' opleidingsrichting toegang verschaft.

Tabel 7.4

Logistische regressie van de kans op richting-aansluitend academisch werk, cohort '89 - '92

\begin{tabular}{|c|c|c|}
\hline & $\begin{array}{l}\text { regressie- } \\
\text { coëfficiënt }\end{array}$ & $\begin{array}{l}\text { standaard- } \\
\text { fout }\end{array}$ \\
\hline $\begin{array}{l}\text { HO-vooropleiding } \\
\text { Werkervaring voor afstuderen } \\
\text { Bestuurlijke ervaring }\end{array}$ & $\begin{array}{r}-.09 \\
.04 \\
-.07\end{array}$ & $\begin{array}{l}.24 \\
.19 \\
.17\end{array}$ \\
\hline $\begin{array}{l}\text { BB } \\
\text { BW } \\
\text { BGK } \\
\text { GGK } \\
\text { GVO } \\
\text { WW } \\
\text { Dagopleiding Ned. recht } \\
\text { Avondopleiding Ned. recht } \\
\text { Economie }\end{array}$ & $\begin{array}{l}-3.38^{\star \star} \\
-2.61^{\star \star} \\
-4.54^{\star *} \\
-3.88^{\star *} \\
-2.87^{\star *} \\
-2.15^{\star \star} \\
-1.41^{\star *} \\
-1.57^{\star \star} \\
-1.77^{\star *}\end{array}$ & $\begin{array}{l}.33 \\
.45 \\
.57 \\
.47 \\
.44 \\
.34 \\
.26 \\
.54 \\
.29\end{array}$ \\
\hline $\begin{array}{l}\text { Mannelijk geslacht } \\
\text { Leeftijd }\end{array}$ & $\begin{array}{r}-.11 \\
.01\end{array}$ & $\begin{array}{l}.18 \\
.03\end{array}$ \\
\hline $\begin{array}{l}\text { Cohort } 90 \\
\text { Cohort } 91 \\
\text { Cohort } 92 \\
\text { Maanden na afstuderen }\end{array}$ & $\begin{array}{l}-.42 \\
-1.36^{* *} \\
-1.29^{* *} \\
-.00\end{array}$ & $\begin{array}{l}.26 \\
.25 \\
.26 \\
.03\end{array}$ \\
\hline Constante & $2.81^{\star \star *}$ & .79 \\
\hline
\end{tabular}

$\begin{array}{ll}* & \text { significant op } 5 \% \text { niveau } \\ * * & \text { significant op } 1 \% \text { niveau }\end{array}$

Model Chi-square $=330.1 ;$ d.f. $=18 ; p<0.01$

Percentage correct $=73$

$n=934$

Naast de gevolgde opleiding blijkt het jaar waarin men is afgestudeerd bepalend te zijn voor de kans om een qua vakgebied passende baan te krijgen. Voor degenen die na 1990 zijn afgestudeerd blijkt deze kans significant groter te zijn dan voor het afstudeercohort '89 (de referentiegroep). Met betrekking tot deze bevinding geldt mutatis mutandis hetzelfde als eerder is opgemerkt bij de kans op niveau- 
aansluitend werk, namelijk dat afgestudeerden in ruil voor een grotere kans op vast werk functies accepteren die gezien hun opleiding minder passend zijn.

\subsection{Samenvatting}

\section{Basisartsen}

De opeenvolgende cohorten basisartsen hebben een onverminderd grote kans om betaald werk op academisch niveau te krijgen. Dit laat onverlet dat basisartsen in toenemende mate uitwijken naar academische functies die ook zouden kunnen worden vervuld door in andere disciplines opgeleide academici. De concurrentie met andere academici neemt dus toe. Bovendien lijkt aan de gestaag toenemende baanzekerheid bij de laatste afstudeerjaargang een einde te zijn gekomen. Ook kan worden geconstateerd dat basisartsen in toenemende mate buiten de regio gaan werken.

\section{Gezondheidswetenschappers}

$\mathrm{Na}$ aanvankelijk te zijn gedaald, neemt de werkloosheid bij de de laatste afstudeerjaargang toe. Dit ondanks het feit dat het laatste cohort gezondheidswetenschappers vaker dan eerdere lichtingen uitwijkt naar functies onder hun academisch niveau. Ook zet de trend dat gezondheidswetenschappers in toenemende mate concurreren met in andere disciplines opgeleide academici zich bij de laatste afstudeerjaargang voort. Dit laat onverlet dat de opeenvolgende cohorten gezondheidswetenschappers er steeds vaker in slagen om vaste aanstellingen te verwerven.

\section{Juristen die de dagopleiding hebben gevolgd}

Bij de cohorten ' $88 \mathrm{t} / \mathrm{m}$ ' 91 heeft de arbeidsmarktintrede, geïndiceerd door de kans op werk, een steeds soepeler verloop te zien gegeven. Daar heeft evenwel tegenover gestaan dat deze cohorten in toenemende mate functies onder hun niveau zijn gaan uitoefenen en dat cohort ' 91 bovendien vaker dan hun voorgangers is uitgeweken naar academische functies die ook zouden kunnen worden vervuld door in andere disciplines opgeleide academici. Ondanks de toegenomen oriëntatie op qua vereist opleidingsniveau en -richting niet-aansluitende banen en de toegenomen oriëntatie op de landelijke arbeidsmarkt, neemt de werkloosheid bij de laatste afstudeerjaargang toe. Dit gaat gepaard met een daling van de baanzekerheid.

\section{Economen}

Wellicht omdat economen vaker uitwijken naar functies onder hun niveau en zich sterker richten op de landelijke arbeidsmarkt, is de werkloosheid bij het laatste cohort afgenomen. Daar staat echter tegenover dat de baanzekerheid ook is afgenomen.

Juristen die de avondopleiding hebben gevolgd

De tweede afstudeerlichting van de avondopleiding Nederlands recht oefent vaker functies op academisch niveau uit en concurreert daarbij sterker met in andere disciplines opgeleide academici dan hun voorgangers. Bovendien is de tweede lichting sterker op de landelijke arbeidsmarkt georiënteerd. Dit laat onverlet dat de twee afstudeerlichtingen nauwelijks verschillen wat de kans op werk en de zekerheid van de baan betreft. 


\section{Schattingsresultaten}

In de vier uitgevoerde analyses kon geen effect worden vastgesteld van het geslacht op de kans op werk, de zekerheid van het werk en de kwaliteit van het werk, geïndiceerd door het niveau en de richting van de opleiding die voor het werk is vereist. Wat de leeftijd betreft, is gebleken dat jongere afgestudeerden een grotere kans hebben om werk te krijgen dan ouderen. Ouderen daarentegen hebben een grotere kans op een vaste aanstelling. De leeftijd heeft geen effect op de kans dat het werk aansluit bij het niveau en de richting van de gevolgde opleiding. Met betrekking tot de extra kwalificaties waarover men eventueel beschikt, is naar voren gekomen dat stapelaars, dit wil zeggen mensen die reeds een hogere opleiding hebben voltooid voordat zij aan de RL zijn gaan studeren, een grotere kans hebben om na het afstuderen werk te vinden. Door betaalde werkervaring, opgedaan voor of tijdens de studie, wordt niet alleen de kans op het vinden van werk na het afstuderen vergroot, maar ook de kans dat het werk qua niveau aansluit bij de gevolgde opleiding. Daarentegen heeft bestuurlijke ervaring, opgedaan voor of tijdens de studie, geen effect op de kans op werk noch op de zekerheid en de kwaliteit van het werk. Profielverbetering middels het opdoen van werkervaring voor of tijdens de studie blijkt bijgevolg effectiever te zijn dan dan een dubbel opleidingstraject en het opdoen van bestuurlijke ervaring.

Verder is naar voren gekomen dat de kans op werk, de zekerheid van het werk en de kwaliteit van het werk samenhangen met de opleidingsrichting die men heeft gevolgd en het jaar waarin men is afgestudeerd. Vergeleken met basisartsen, die in de analyses als referentiegroep fungeerden, hebben afgestudeerden van de andere opleidingsrichtingen een kleinere kans op werk (behoudens oudavondstudenten Nederlands recht) en een kleinere kans dat het werk qua niveau en richting aansluit op de gevolgde opleiding. Echter, vergeleken met basisartsen hebben de afgestudeerden van de andere opleidingsrichtingen (behoudens oudstudenten BGK en GGK) een grotere kans op een vaste aanstelling. Tenslotte is in de uitgevoerde analyses gebleken dat degenen die na 1990 zijn afgestudeerd weliswaar geen grotere kans hebben om werk te vinden dan afstudeercohort ' 89 (de referentiegroep), maar wel een grotere kans hebben dat het werk vast is. Daar staat evenwel een kleinere kans tegenover dat het gevonden werk qua niveau en richting aansluit op de gevolgde opleiding. Blijkbaar accepteren de recentere afstudeercohorten, in ruil voor een grotere baanzekerheid, functies die gezien hun opleiding minder passend zijn. Tenslotte blijkt, zoals kan worden verwacht, dat de kans op werk toeneemt naarmate men meer tijd heeft gehad om werk te zoeken. 


\section{Samenvatting en conclusies}

\subsection{Afstudeercohort' '92}

Dit rapport bevat de resultaten van de basismeting, die najaar 1993 is verricht onder degenen die in het kalenderjaar 1992 aan de RL zijn afgestudeerd. In deze paragraaf worden eerst de belangrijkste bevindingen met betrekking tot afstudeercohort ' 92 samengevat. Vervolgens komen in paragraaf 8.2 de bevindingen aan bod van de vergelijking van de arbeidsmarktintrede van de vijf afstudeercohorten, die tot nu toe met behulp van de basisvragenlijsten zijn geëënquêteerd, namelijk de afstudeerjaargangen ' $88 \mathrm{t} / \mathrm{m}$ '92.

\section{Kenmerken respondenten}

Afstudeerjaargang ' 92 bestaat voor meer dan de helft $(63 \%)$ uit vrouwen. Het aandeel van vrouwen is het hoogst onder gezondheidswetenschappers en het laagst onder economen. De gemiddelde leeftijd bij afstuderen bedraagt 26,9 jaar. De afgestudeerden van de nominaal zevenjarige avondopleiding Nederlands recht zijn gemiddeld het oudst en economen het jongst. Driekwart van de afgestudeerden is vanuit het WWO aan de RL gaan studeren. Gezondheidswetenschappers en oud-avondstudenten Nederlands recht hebben vaak een HBO-opleiding hebben voltooid voordat zij aan de RL gaan studeren. Zes van iedere tien afgestudeerden heeft vóór of tijdens de studie betaalde werkervaring opgedaan. Bijna de helft heeft vóór of tijdens de studie bestuurlijke ervaring opgedaan.

Intrede op de arbeidsmarkt

Bij alle faculteiten kan worden geconstateerd dat de meeste afgestudeerden die zich op de arbeidsmarkt aanbieden niet of hoogstens 3 maanden werkloos zijn geweest, voorafgaand aan de eerste betaalde baan. Afgestudeerden van de avondopleiding Nederlands recht zijn het vaakst werkzaam wanneer zij afstuderen.

Op het moment van enquêtering (een tot anderhalf jaar na het afstuderen) is $6 \%$ van de respondenten niet beschikbaar voor de arbeidsmarkt omdat men full-time additioneel onderwijs volgt. Afgestudeerden van de dagopleiding Nederlands recht volgen vaker dan anderen full-time additioneel onderwijs. De werkloosheid onder afgestudeerden die zich op de arbeidsmarkt aanbieden, bedraagt op het moment van enquêtering $9 \%$. Alle basisartsen en oud-avondstudenten Nederlands recht die zich op de arbeidsmarkt aanbieden, doen dit met goed gevolg: niemand van hen is werkloos. De werkloosheidspercentages onder afgestudeerden van de andere faculteiten die zich op de arbeidsmarkt aanbieden, variëren van $6 \%$ onder economen en $10 \%$ onder gezondheidswetenschappers tot $14 \%$ onder juristen die de dagopleiding hebben gevolgd.

\section{Baanmobiliteit}

Ruim de helft (68\%) van de betaald werkenden is een tot anderhalf jaar na het afstuderen nog steeds bij de eerste werkgever werkzaam; bijna een kwart $(24 \%)$ is bij de huidige werkgever al eens van functie veranderd. Juristen die de avondopleiding hebben gevolgd, werken het vaakst nog steeds bij dezelfde eerste werkgever en zijn het vaakst al eens van functie veranderd bij hun huidige werkgever. Bovendien zijn zij, samen met economen, minder vaak dan anderen op zoek naar een andere baan. 


\section{Branche en beroep}

Voor basisartsen zijn algemene, niet-academische ziekenhuizen (59\%) de belangrijkste bron van werkgelegenheid; voor gezondheidswetenschappers zijn dit de universiteiten (14\%) en medisch/verpleegkundige diensten (13\%). Voor juristen zijn algemene overheidsbesturen (35\%) de belangrijkste werkgevers. De meeste economen zijn bij accountantskantoren gaan werken (23\%). Vergeleken met andere afgestudeerden zijn basisartsen in een smalle 'range' van bedrijfsgroepen werkzaam. Bovendien hebben basisartsen een nauw afgebakend beroependomein.

lets meer dan de helft (58\%) van de afgestudeerden werkt in grote organisaties met meer dan honderd personeelsleden. Vrijwel alle afgestudeerden komen terecht op de Nederlandse arbeidsmarkt (juristen die de avondopleiding hebben gevolgd bovendien in meerderheid op de regionale arbeidsmarkt). Van de betaald werkende afgestudeerden werkt $3 \%$ in het buitenland. Economen zijn vaker dan andere afgestudeerden van de RL in het buitenland, namelijk in andere EG-landen, werkzaam.

De meerderheid $(80 \%)$ van afstudeercohort '92 neemt bestaande functies binnen werkorganisaties in. Gezondheidswetenschappers bekleden iets vaker dan anderen ook nieuwe functies.

\section{Functiekenmerken}

Reageren op een advertentie (24\%), ongevraagd ('open') solliciteren (22\%) en stage-contacten (12\%) vormen de drie belangrijkste kanalen waarmee afgestudeerden hun intredebaan verkrijgen. Advertenties zijn met name voor oudstudenten van de dagopleiding Nederlands recht van belang, en open sollicitaties vooral voor basisartsen en economen. Stagecontacten blijken belangrijker te zijn voor gezondheidswetenschappers dan voor andere afgestudeerden.

Vrijwel alle betaald werkenden (96\%) werken in loondienst, waarvan ruim de helft (58\%) in een tijdelijke aanstelling. Basisartsen hebben vaker dan anderen tijdelijke aanstellingen, in het bijzonder aanstellingen voor langer dan een jaar. De overgrote meerderheid van de oud-avondstudenten Nederlands recht werkt in een vaste baan. Ruim driekwart $(78 \%)$ van de betaald werkende oudstudenten heeft een full-time baan. Gezondheidswetenschappers werken vaker dan anderen ook in deeltijdbanen. Basisartsen hebben de langste werkweken. Gezondheidswetenschappers werken gemiddeld het kortst.

Circa een jaar na het afstuderen oefenen de meeste $(79 \%)$ betaald werkende afgestudeerden nog geen leidinggevende functie uit. Het bruto maandinkomen bij een veertigurige werkweek bedraagt gemiddeld fl 4.007,-- Tussen de afzonderlijke studierichtingen zijn de inkomensverschillen doorgaans vrij groot. Oudstudenten van de avondopleiding Nederlands recht en basisartsen hebben gemiddeld de hoogste inkomens.

\section{Aansluiting studie-functie}

Twee derde van de betaald werkenden heeft een functie waarvoor, naar eigen zeggen, een opleiding op academisch niveau is vereist. Basisartsen zijn vrijwel uitsluitend in functies op academisch niveau werkzaam. Voor bijna een derde (31\%) van de functies werd de aan de RL gevolgde opleidingsrichting specifiek door de werkgever gevraagd (basisartsen komen het meest in dit soort functies terecht). Ruim een derde (37\%) van de functies zou volgens de afgestudeerden ook kunnen worden vervuld door mensen met een verwante opleidingsrichting; $15 \%$ wijkt uit naar functies waarvoor een andere opleidingsrichting werd gevraagd dan de richting die men aan de RL heeft gevolgd. Circa een zesde (17\%) oefent 
algemene functies uit, waarvoor het niet noodzakelijk is dat men in een bepaalde richting is afgestudeerd.

Een vijfde van de betaald werkenden combineert verder leren en werken in de functie, hetzij als AIO of OIO (6\%) hetzij door het volgen van post-doctorale beroepsopleidingen (14\%). De laatstgenoemde opleidingen worden het vaakst gevolgd door economen. Er zijn meer basisartsen die een medische opleidingsplaats zoeken dan basisartsen die een medische opleidingsplaats hebben gevonden.

\subsection{Cohortontwikkelingen}

In de uitgevoerde analyses is naar voren gekomen dat degenen die na 1990 zijn afgestudeerd een grotere kans hebben om een vaste aanstelling te verwerven dan afstudeercohort ' 89 (de referentiegroep). Daar staat evenwel een kleinere kans tegenover dat het gevonden werk qua niveau en richting aansluit op de gevolgde opleiding. Blijkbaar accepteren de recentere afstudeercohorten, in ruil voor een grotere baanzekerheid, functies die gezien hun opleiding minder passend zijn. Ondanks het feit dat afgestudeerden in toenemende mate zijn uitgeweken naar functies waarvoor een academische opleiding niet is vereist en functies die ook open staan voor in andere disciplines opgeleide academici, is hun kans om werk te vinden niet significant toegenomen.

De niet langer dalende werkloosheid en het toenemend uitwijken naar niet bij de opleiding passende functies in ruil voor een grotere baanzekerheid vormen indicaties voor de toenemend onzekere arbeidsmarktsituatie waarmee intrede academici worden geconfronteerd. Binnen de marges van dit algemene beeld varieert de hierboven geschetste ontwikkeling evenwel naar faculteit (zie paragraaf 7.3).

Bij de laatste afstudeerjaargang lijkt de arbeidsmarktsituatie overigens nog verder te zijn verslechterd. Immers, hoewel de ontwikkeling van het gestaag toenemend uitwijken naar functies onder het opleidingsniveau zich ook bij cohort ' 92 nog voortzet, neemt de baanzekerheid niet langer gestaag toe. 



\section{Literatuur}

Centraal Bureau voor de Statistiek (1982), Standaard bedrijfsindeling bedrijfstelling 1978, CBS.

Centraal Bureau voor de Statistiek (1984), Beroepenclassificatie 1984, CBS, Voorburg.

Grip, A. de, R.K.W. van der Velden, M.H. Wieling (1993), De arbeidsmarktpositie van MDGO-schoolverlaters, in Tijdschrift voor Arbeidsmarktvraagstukken, jrg. 9, 1993/3, blz. 241-252, Academische uitgeverij Amersfoort, Amersfoort.

Ramaekers, G.W.M., J.A.M. Heijke (1991), Arbeidsmarktscanner Rijksuniversiteit Limburg: Afgestudeerden 1986-1989, ROA-R-1991/6, Maastricht.

Ramaekers, G.W.M., J.A.M. Heijke (1993-1), Arbeidsmarktscanner Rijksuniversiteit Limburg: Basismeting cohort '90, ROAR-1993/1, Maastricht.

Ramaekers, G.W.M., J.A.M. Heijke (1993-2), Arbeidsmarktscanner Rijksuniversiteit Limburg: Basismeting cohort '91, ROAR-1993/13, Maastricht.

Velden, R.K.W. van der, M.H. Wieling (1994), De arbeidsmarktkansen per opleiding, in: Arbeidsmarkt en Sociale Zekerheid, Beleid in Beweging, blz. 106-114, H. Scholten, S.C. de Groot (red), IVA Tilburg, Eburon Delft. 


\section{Bijlage 1 Tabellen afstudeerrichtingen FdGW en FdEW}

\section{A. FdGW}

Bij de afstudeercohorten '88-'92 van de FdGW zijn de respondenten als volgt over de afstudeervarianten verdeeld.

\begin{tabular}{lrr}
\hline & $n$ & $\%$ \\
\hline beleid en beheer van gezondheidszorgvoorzieningen (BB) & 195 & 22 \\
bewegingswetenschappen (BW) & 109 & 12 \\
biologische gezondheidkunde (BGK) & 94 & 11 \\
theorie der gezondheidswetenschappen (TGW) & 20 & 2 \\
geestelijke gezondheidkunde (GGK) & 106 & 12 \\
gezondheidsvoorlichting (GVO) & 122 & 14 \\
verplegingswetenschap (MW) & 229 & 26 \\
Totaal & 875 & 100 \\
\hline
\end{tabular}

Vanwege het geringe aantal respondenten die TGW hebben gevolgd, mag aan de cijfers met betrekking tot deze afstudeervariant slechts relatieve waarde worden toegekend.

Tabel A.1

Maatschappelijke positie, één jaar na afstuderen, cohort '88-'92 naar afstudeerrichting FdGW

\begin{tabular}{lrrrrrrrr}
\hline & BB & BW & BGK & FT & GGK & GVO & WW & Totaal \\
\hline betaald werk & $86 \%$ & $62 \%$ & $78 \%$ & $70 \%$ & $66 \%$ & $70 \%$ & $86 \%$ & $77 \%$ \\
dienstplicht & $2 \%$ & $1 \%$ & $2 \%$ & $5 \%$ & $1 \%$ & $2 \%$ & $0 \%$ & $1 \%$ \\
student 4\% & $18 \%$ & $6 \%$ & $5 \%$ & $8 \%$ & $9 \%$ & $6 \%$ & $8 \%$ & $3 \%$ \\
onbetaald werk & $1 \%$ & $2 \%$ & $4 \%$ & $5 \%$ & $6 \%$ & $5 \%$ & $1 \%$ & $8 \%$ \\
werkzoekend & $7 \%$ & $12 \%$ & $5 \%$ & $15 \%$ & $11 \%$ & $10 \%$ & $5 \%$ & $3 \%$ \\
andere situatie, nl. & $1 \%$ & $5 \%$ & $4 \%$ & $0 \%$ & $8 \%$ & $4 \%$ & $2 \%$ & \\
Totaal n(=100\%) & 195 & 109 & 94 & 20 & 106 & 122 & 229 & 875 \\
\hline
\end{tabular}

\section{Tabel A.2}

Belangrijkste beroepen ${ }^{15}$, cohort ' $88-' 92$ naar afstudeerrichting FdGW

BB:

beleidsmedewerker op medisch/paramedisch vakgebied

beleidsmedewerker op overig vakgebied

beleidsmedewerker, vakgebied onbekend

sociaal-wetenschappelijk onderzoeker, sociologisch onderzoeker, (bedrijfs)socioloog

bedrijfsorganisatiedeskundige

- projectadviseur probleemanalist, informatie-analist

BW:

- wetenschappelijk onderzoeker op medisch vakgebeid

wetenschappelijk onderzoeker op paramedisch vakgebeid

wetenschappelijk ambtenaar/onderzoeker op ander vakgebied

$(10 \%)$

beleidsmedewerker

docent

bewegingstherapeut

biochemicus/fysicus, bacterioloog, farmacoloog, toxicoloog e.d.

- technisch vertegenwoordiger, waaronder artsenbezoeker

- sociaal-wetenschappelijk onderzoeker, sociologisch onderzoeker, (bedrijfs)socioloog

15. Beroepen met een aandeel van tenminste $5 \%$. 
BGK:

- biochemicus/fysicus, bacterioloog, farmacoloog, toxicoloog e.d.

- wetenschappelijk onderzoeker op medisch vakgebied

- wetenschappelijk onderzoeker op paramedisch vakgebied $\quad(6 \%)$

- technisch vertegenwoordiger, waaronder artsenbezoeker

- beleidsmedewerker $\quad(6 \%)$

TGW:

sociaal-wetenschappelijk onderzoeker, sociologisch onderzoeker, (bedrijfs)socioloog

beleidsmedewerker

wetenschappelijk onderzoeker op medisch/paramedisch vakgebied

verpleegkundige

onderwijskundig adviseur

biochemicus/fysicus, bacterioloog, farmacoloog, toxicoloog e.d.

$(14 \%)$

$(7 \%)$

$(7 \%)$

GGK:

- medisch, psychiatrisch maatschappelijk werker, GVO-functionaris

- overig maatschappelijk werker

- wetenschappelijk onderzoeker op paramedisch vakgebied

wetenschappelijk onderzoeker op medisch vakgebied

sociaal-wetenschappelijk onderzoeker, sociologisch onderzoeker, (bedrijfs)socioloog

psycholoog/pedagoog

beleidsmedewerker

docent

GVO:

- medisch, psychiatrisch maatschappelijk werker, GVO-functionaris

sociaal-wetenschappelijk onderzoeker, sociologisch onderzoeker, (bedrijfs)socioloog

wetenschappelijk onderzoeker op medisch/paramedisch vakgebied

W:

- hoofdverpleegkundige, staffunctionaris verpleging

beleidsmedewerker op medisch/paramedisch vakgebied

verpleegkundige

docent

Tabel A.3

Gemiddeld bruto maandinkomen bij een volledige werkweek, circa één jaar na afstuderen, cohort '88-'92 naar afstudeerrichting FdGW

\begin{tabular}{lrrrrrrr}
\hline & BB & BW & BGK & FT & GGK & GVO & WW \\
\hline $\begin{array}{l}\text { Maandinkomen } \\
\text { Standaardafwijking }\end{array}$ & $\begin{array}{rrrr}3949,34 \\
982,22\end{array}$ & $\begin{array}{r}3358,39 \\
948,03\end{array}$ & $\begin{array}{r}3020,73 \\
1066,25\end{array}$ & $\begin{array}{r}3321,37 \\
2627,13\end{array}$ & $\begin{array}{r}3492,61 \\
1036,74\end{array}$ & $\begin{array}{r}3522,91 \\
789,10\end{array}$ & $\begin{array}{l}4456,90 \\
1502,46\end{array}$ \\
\hline
\end{tabular}

Tabel A.4

Opleidingseisen voor de functie die men circa één jaar na afstuderen heeft, cohort '89-'92 naar afstudeerrichting FdGW

\begin{tabular}{lrrrrrrrr}
\hline & BB & BW & BGK & FT & GGK & GVO & WW & Totaal \\
\hline onder WO-niveau & $31 \%$ & $42 \%$ & $19 \%$ & $14 \%$ & $27 \%$ & $50 \%$ & $40 \%$ & $35 \%$ \\
$\begin{array}{l}\text { WO-niveau: } \\
\text { GW niet vereist }\end{array}$ & $53 \%$ & $32 \%$ & $74 \%$ & $79 \%$ & $60 \%$ & $33 \%$ & $37 \%$ & $48 \%$ \\
GW wel, afstudeerrichting & $1 \%$ & $4 \%$ & $0 \%$ & $0 \%$ & $3 \%$ & $3 \%$ & $3 \%$ & $2 \%$ \\
$\begin{array}{l}\text { niet vereist } \\
\text { Afstudeerrichting binnen GW } \\
\text { vereist }\end{array}$ & $15 \%$ & $22 \%$ & $6 \%$ & $7 \%$ & $10 \%$ & $14 \%$ & $20 \%$ & $15 \%$ \\
Totaal n(=100\%) & 143 & 50 & 62 & 14 & 63 & 70 & 181 & 583 \\
\hline
\end{tabular}

GW = Gezondheidswetenschappen 


\section{B. FdEW}

Bij de afstudeercohorten '88-'92 van de FdEW zijn de respondenten als volgt over de afstudeervarianten verdeeld.

\begin{tabular}{lrc}
\hline & $n$ & $\%$ \\
\hline algemene economie (AE) & 34 & 12 \\
bedrijfseconomie (BE) & 196 & 71 \\
internationaal management (IM) & 36 & 13 \\
kwantitatieve economie (KE) & 1 & 4 \\
vrij doctoraal tracé (VD) & 10 & 100 \\
Totaal & 277 & \\
\hline
\end{tabular}

In de tabellen worden geen cijfers met betrekking tot KE en VD gepresenteerd, vanwe de geringe aantallen respondenten die deze afstudeervarianten hebben gevolgd. Deze respondenten zijn wel meegerekend in de totaalkolommen van de tabellen.

Tabel B.1

Maatschappelijke positie, één jaar na afstuderen, cohort '88-'92 naar afstudeerrichting FdEW

\begin{tabular}{|c|c|c|c|c|}
\hline & $A E$ & $B E$ & IM & Totaal \\
\hline $\begin{array}{l}\text { betaald werk } \\
\text { dienstplicht } \\
\text { student } \\
\text { onbetaald werk } \\
\text { werkzoekend } \\
\text { andere situatie, nl. }\end{array}$ & $\begin{array}{r}82 \% \\
3 \% \\
6 \% \\
0 \% \\
9 \% \\
0 \%\end{array}$ & $\begin{array}{r}88 \% \\
4 \% \\
1 \% \\
1 \% \\
6 \% \\
1 \%\end{array}$ & $\begin{array}{r}78 \% \\
8 \% \\
8 \% \\
0 \% \\
6 \% \\
0 \%\end{array}$ & $\begin{array}{r}86 \% \\
5 \% \\
3 \% \\
0 \% \\
6 \% \\
1 \%\end{array}$ \\
\hline Totaal $n(=100 \%)$ & 34 & 196 & 36 & 278 \\
\hline
\end{tabular}

Tabel B.2

Belangrijkste beroepen ${ }^{16}$, cohort '88-'92 naar afstudeerrichting FdEW

AE:

- economist, (bedrijfs)econoom, sociaal-economisch onderzoeker

- beleidsmedewerker op economisch vakgebied

$B E$ :

- assistent-accountant

(bedriifs)accountant

economist, (bedrijfs)econoom, sociaal-economisch onderzoeker

hoger/middelbaar employé

$(12 \%)$

- beleidsmedewerker

- hoofd afdeling

marketing-specialist/-assistent

(5\%)

- docent

IM:

- docent

- beleidsmedewerker op economisch vakgebied

- hoofd afdeling verkoop/marketing

- marketing-specialist

marketing-assistent

hoger/middelbaar employé

16. Beroepen met een aandeel van tenminste $5 \%$. 
Tabel B.3

Gemiddeld bruto maandinkomen bij een volledige werkweek, circa één jaar na afstuderen, cohort '88-'92 naar afstudeerrichting FdEW

\begin{tabular}{lrrr}
\hline & AE & BE & IM \\
\hline Maandinkomen & 3066,76 & 3921,75 & 4366,33 \\
Standaardafwijking & 1242,71 & 827,24 & 891,89 \\
\hline
\end{tabular}

Tabel B.4

Opleidingseisen voor de functie die men circa één jaar na afstuderen heeft, cohort '89-'92 naar afstudeerrichting FdEW

\begin{tabular}{lcccc}
\hline & AE & BE & IM & Totaal \\
\hline onder WO-niveau & $8 \%$ & $32 \%$ & $28 \%$ & $29 \%$ \\
WO-niveau: & & & $40 \%$ & $33 \%$ \\
EW niet vereist & $44 \%$ & $30 \%$ & $28 \%$ & $13 \%$ \\
EW wel, afstudeerrichting niet vereist & $20 \%$ & $10 \%$ & $4 \%$ & $25 \%$ \\
Afstudeerrichting binnen EW vereist & $28 \%$ & $28 \%$ & 25 & 204 \\
Totaal n(=100\%) & 25 & 146 & & \\
\hline
\end{tabular}

$\overline{\mathrm{EW}}=$ Economische Wetenschappen 


\section{Bijlage 2 Definitie van variabelen in de schattingen}

\section{Te verklaren variabelen}

Kans op werk

0 respondent is op zoek naar en beschikbaar voor betaald werk voor tenminste 12 uur per week

1 respondent verricht tenminste 12 uur per week betaald werk of vervult militaire of vervangende dienst

Kans op vast werk

0 in loondienst werkende respondent heeft een tijdelijke aanstelling ( $<61$ maanden), excl. militaire of vervangende dienst

1 in loondienst werkende respondent heeft een vaste aanstelling (> 60 maanden), excl. militaire of vervangende dienst

Niveau-aansluitend werk

0 functie waarvoor volgens opgave van de respondenten een wetenschappelijke opleiding niet is vereist (excl. militaire of vervangende dienst)

1 functie waarvoor volgens opgave van de respondenten een wetenschappelijke opleiding wel is vereist (excl. militaire of vervangende dienst)

Richting-aansluitend academisch werk

0 academische functie waarvoor volgens opgave van de respondenten de aan de $\mathrm{RL}$ gevolgde opleidingsrichting niet specifiek is vereist (excl. militaire of vervangende dienst)

1 academische functie waarvoor volgens opgave van de respondenten de aan de RL gevolgde opleidingsrichting specifiek is vereist (excl. militaire of vervangende dienst)

\section{Verklarende variabelen}

Mannelijk geslacht

0 vrouw

1 man

Leeftijd

leeftijd in jaren op moment van afstuderen

HO-vooropleiding

0 beschikt niet over HBO- of WO-diploma voor aanvang van RL-studie

1 beschikt wel over HBO- of WO-diploma voor aanvang van RL-studie

Werkervaring voor afstuderen

0 geen betaalde werkervaring opgedaan vóór afstuderen

1 wel betaalde werkervaring opgedaan vóór afstuderen

Bestuurlijke ervaring voor afstuderen

0 geen bestuurlijke ervaring opgedaan vóór afstuderen

1 wel bestuurlijke ervaring opgedaan vóór afstuderen 


\section{Cohort ' 89}

0 in 1990, 1991 of 1992 afgestudeerd

1 in 1989 afgestudeerd

\section{Cohort '90}

0 in 1989, 1991 of 1992 afgestudeerd

1 in 1990 afgestudeerd

Cohort ' 91

0 in 1989, 1990 of 1992 afgestudeerd

1 in 1991 afgestudeerd

Cohort ' 92

0 in 1989, 1990 of 1991 afgestudeerd

1 in 1992 afgestudeerd

\section{Geneeskunde}

0 afgestudeerd in andere studie dan geneeskunde

1 afgestudeerd in geneeskunde

\section{BB}

0 afgestudeerd in andere studie dan beleid en beheer

1 afgestudeerd in beleid en beheer

\section{GVO}

0 afgestudeerd in andere studie dan gezondheidsvoorlichting

1 afgestudeerd in gezondheidsvoorlichting

$\mathrm{VW}$

0 afgestudeerd in andere studie dan verplegingswetenschap

1 afgestudeerd in verplegingswetenschap

\section{BGK}

0 afgestudeerd in andere studie dan biologische gezondheidkunde

1 afgestudeerd in biologische gezondheidkunde

\section{GGK}

0 afgestudeerd in andere studie dan geestelijke gezondheidkunde

1 afgestudeerd in geestelijke gezondheidkunde

BW

0 afgestudeerd in andere studie dan bewegingswetenschappen

1 afgestudeerd in bewegingswetenschappen

Avondopleiding Ned. recht

0 afgestudeerd in andere studie dan de avondopleiding Nederlands recht

1 afgestudeerd in de avondopleiding Nederlands recht 
Dagopleiding Ned. recht

0 afgestudeerd in andere studie dan de dagopleiding Nederlands recht

1 afgestudeerd in de dagopleiding Nederlands recht

\section{Economie}

0 afgestudeerd in andere studie dan economie

1 afgestudeerd in economie

Maanden na afstuderen

Aantal maanden dat men reeds is afgestudeerd 


\section{Bijlage 3 ROA-publicaties in het kader van de arbeidsmarktscanner}

1988

Dam, J.W. van, A. de Grip, J.A.M. Heijke (1988), Op zoek naar informatiebronnen over de arbeidsmarktpositie van academici, ROA-W-1988/3, Maastricht.

1989

Dam, J.W. van, J.A.M. Heijke, G.W.M. Ramaekers (1989), Ontwerp van een arbeidsmarktscanner voor academici, ROA-R-1989/3, Maastricht.

1990

Dam, J.W. van, A. de Grip, J.A.M. Heijke (1990), Huidig follow-up onderzoek levert dikwijls beperkte resultaten, in: Universiteit en Hogeschool, jrg. 36, nr. 4, blz. 260-266.

Dam, J.W. van, J.A.M. Heijke, G.W.M. Ramaekers (1990), Gecoördineerd arbeidsmarktonderzoek onder hoger opgeleiden: methodiek en resultaat. Naar vergelijkbaarheid door standaardisatie, in: Universiteit en Hogeschool, jrg. 37, nr. 2, blz. 82-91.

Ramaekers, G.W.M., J.A.M. Heijke (1990), Proefonderzoek arbeidsmarktscanner afgestudeerden Rijksuniversiteit Limburg, ROA-W-1990/3, Maastricht.

1991

Lodder, B.J.H., P.E.J. van de Loo, G.W.M. Ramaekers, R.K.W. van der Velden (1991), Arbeidsmarktindicatoren ten behoeve van het emancipatiebeleid van de Rijksuniversiteit Limburg, ROA-R-1991/7, Maastricht.

Ramaekers, G.W.M., J.A.M. Heijke (1991), Arbeidsmarktscanner Rijksuniversiteit Limburg: Afgestudeerden 1986-1989, ROA-R-1991/6, Maastricht.

1992

Heijke, J.A.M., G.W.M. Ramaekers (1992), Labour Market Position of University of Limburg Graduates, ROA-RM-1992/2E, Maastricht.

Heijke, J.A.M., G.W.M. Ramaekers (1992), De arbeidsmarktpositie van afgestudeerden van de Rijksuniversiteit Limburg 1986-1989, op basis van de arbeidsmarktscanner, in: Tijdschrift voor Hoger Onderwijs, jrg. 10, nr. 3, blz. 168-188.

Lodder, B.J.H., P.E.J. van de Loo, G.W.M. Ramaekers, R.K.W. van der Velden (1992), Sex differences in the labour market position of young graduates, in: Tj. Plomp, J.M. Pieters, A. Feteris (ed), European Conference on Educational Research: Book of Summaries. Volume 3, pp. 1057-1059, University of Twente, June 1992, Enschede.

Ramaekers, G.W.M., J.A.M. Heijke (1992), De arbeidsmarktpositie van aan de RL afgestudeerde basisartsen, in: Kozijn, april '92, nr. 6, blz. 12-13. 